\title{
Evidence of melting, melt percolation and deformation in a supra-subduction zone (Marum ophiolite complex, Papua New Guinea)
}

\author{
Mary-Alix Kaczmarek ${ }^{1,2} \cdot$ Leo Jonda $^{3} \cdot$ Hugh L. Davies $^{3}$
}

Received: 3 February 2015 / Accepted: 16 July 2015 / Published online: 4 August 2015

(C) Springer-Verlag Berlin Heidelberg 2015

\begin{abstract}
New geochemical and microstructural data are presented for a suite of ultramafic rocks from the Marum ophiolite in Papua New Guinea. Our results describe a piece of most depleted mantle made essentially of dunite and harzburgite showing compositions of supra-subduction zone peridotite. Strong olivine crystallographic preferred orientations (CPOs) in dunite and harzburgite inferred the activation of both (001)[100] and (010)[100] slip systems, which are activated at high-temperature and low-stress conditions. Clinopyroxene and orthopyroxene CPOs inferred the activation of (100)[001] and (010) [001] slip systems, which are common for pyroxenes deformed at high temperature. This plastic deformation is interpreted to have developed during the formation of the Marum ophiolite, prior to melt percolation. The orientation of the foliation and olivine [100] slip directions sub-parallel to the subduction zone indicates that mantle flow was parallel to the trench pointing a fast polarisation
\end{abstract}

Communicated by Timothy L. Grove.

Electronic supplementary material The online version of this article (doi:10.1007/s00410-015-1174-z) contains supplementary material, which is available to authorized users.

Mary-Alix Kaczmarek

mary-alix.kaczmarek@unil.ch

1 Géosciences Montpellier, Université Montpellier 2 \& CNRS, Place E. Bataillon, 34095, Montpellier Cedex 5, France

2 Present Address: Institute for Earth Sciences (ISTE), University of Lausanne, UNIL Mouline, Géopolis, 1015 Lausanne, Switzerland

3 Earth Sciences Division, University of Papua New Guinea, P.O. Box 414, University NCD, Port Moresby, Papua New Guinea direction parallel to the arc. This provides new evidence that fast polarisation direction parallel to the arc could be caused by anisotropic peridotite and not by olivine [001] slip. After its formation, Marum ophiolite has been fertilised by diffuse crystallisation of a low proportion of clinopyroxene (1-2 \%) (P1) and formation of cm-scale ol-clinopyroxenite and ol-websterite veins cross-cutting the foliation (P2). This percolating melt shows silicarich magnesian affinities (boninite-like) related to suprasubduction zone in a young fore-arc environment. The peridotite has also been percolated by a melt with more tholeiite affinities precipitating plagioclase-rich wehrlite and thin gabbroic veins (P3); these are interpreted to form after the boninitic event. The small proportion of newly crystallised pyroxene in the dunite shows similar orientation of crystallographic axes to the host dunite $(<100\rangle_{\text {ol }}$ parallel to $\langle 001\rangle_{\mathrm{cpx}-\mathrm{opx}}$ ). In contrast, the pyroxenes in olclinopyroxenite, ol-websterite and the thin gabbroic veins in the wehrlite, record their own orientation with $<001>$ axes at $45^{\circ}-60^{\circ}$ to olivine $<100>$ axes. Our results indicate that for low melt proportion the crystallisation is governed by epitaxial growth, and when the proportion of melt is higher the newly formed minerals record synkinematic crystallisation. This switch of crystallographic axes orientation of newly formed minerals indicates a reorientation of the constraints during the boninitic and tholeiitic melts event probably due to a variation of lateral mantle flow within the fore-arc area. The variation of the crystallographic axes orientation could be an indicator for the development of a young fore-arc mantle in suprasubduction zone.

Keywords Marum ophiolite Depleted peridotite . Fore-arc $\cdot$ Melt percolation $\cdot$ EBSD $\cdot$ E- and A-type fabrics $\cdot$ Arc-parallel flow 


\section{Introduction}

Ophiolites have been actively investigated in order to reconstruct margin histories in different geodynamic settings. Direct samples of the mantle wedge can be drilled, dredged (e.g. Izu Bonin Mariana arc, Parkinson and Pearce 1998), carried to the surface by subduction-related magmas (e.g. Papua New Guinea, Franz et al. 2002; Kamchatka, Ionov 2010; Philippine, Maury et al. 1992) or by obducted ophiolite, which occupied the fore-arc zone prior to arccontinent collision (New-Caledonia, Marchesi et al. 2009; Oman, Tamura and Arai 2006). In subduction zone, large amounts of melt and fluids derived from the subducted slab will change the geochemistry and the rheology of the mantle sequence. Most studies on mantle from supra-subduction zones (SSZs) focus on geochemistry of slab-derived melt and mantle wedge melt to constrain the composition and evolution of the melts during melting and melt-rocks reactions in the mantle wedge processes (e.g. Bizimis et al. 2000; Choi et al. 2008; Grégoire et al. 2001; Ionov 2010; Maury et al. 1992; Parkinson and Pearce 1998). However, studies of the deformation history of mantle rocks in subduction zones are still rare (e.g. Michibayashi et al. 2009; Park and Jung 2014; Song and Su 1998; Soustelle et al. 2010; Tasaka et al. 2008) even though experimental and modelling studies of deformation processes in the mantle wedge have been developed during the last decades (Jung and Karato 2001; Kneller and van Keken 2008; Kneller et al. 2005). Moreover, it has been shown that the presence of melt could change the rheology of the mantle and lead to the localisation of deformation (Holtzman and Kohlstedt 2007; Holtzman et al. 2003), but only rare studies in SSZ investigated both melt and deformation processes (e.g. Michibayashi et al. 2009).

The Papua New Guinea (PNG) ophiolites have been investigated through extensive field mapping to decipher the structure of the complexes, and their geochemistry has been characterised in a limited number of studies (Davies 2012; Davies and Jaques 1984; Jaques 1980). The ophiolites and marginal basins of the New Guinea region provide a range of massifs from west to east: April, Marum and the Papuan Ultramafic Belt (PUB) (Davies 1971; Davies and Smith 1971). The three complexes occupy a similar structural position in the New Guinea mountain system but represent different tectonomagmatic settings. In each setting the subduction of the leading edge of the Australian continental margin has stacked a refractory fore-arc basement over a non-refractory lithosphere of the lower plate. In this environment, the Marum ophiolite represents a frozen piece of fore-arc mantle wedge, in an intermediate composition between refractory and fertile composition (Davies and Jaques 1984; Jaques 1981). Therefore, the Marum ophiolite offers the opportunity to reconstruct the evolution of oceanic crust at various stages of subduction.

The Marum ophiolite is an excellent case study to characterise the relationships between the composition of the upper mantle, melt percolation processes and mantle deformation in a SSZ setting within a large structural framework. Here we combined field observations, chemical composition of minerals in terms of major and trace elements and crystallographic preferred orientations (CPOs) of minerals in the Marum ophiolite to discuss the evolution of melt processes recorded by the mantle above the subducting plate.

\section{Geological setting}

\section{New Guinea ophiolites}

The New Guinea Island has the outline of a giant bird flying westward and is at the interface between the northward moving Australian plate and the WNW-moving Pacific Plate. The southern half of the island is part of the Australian continent, and the northern part has been built up by successive collisions with micro-continents and volcanic islands of the Pacific (Davies 2012; Fig. 1). Since the Mesozoic, the oblique convergence between the Australian and Pacific plates (Baldwin et al. 2012; Daly et al. 1991; Pubellier et al. 1996), produced subduction zones and the obduction of pieces of oceanic lithospheres that are now incorporated into the Australian margin (Fig. 1).

The island contains several ophiolite bodies, which are part of an incomplete chain of ophiolites. The main ophiolite bodies are Cyclops, High-Chain and Weyland in Indonesian part and April, Marum and PUB in the PNG part of the island (Fig. 1). The ophiolite bodies are segments of oceanic lithosphere, which occupied the fore-arc zone prior to arc-continent collision (Davies and Jaques 1984; Jaques 1981). Dating of Cape Vogel intra oceanic lavas (boninites and tholeiites) near the PUB at $59-58 \mathrm{Ma}\left({ }^{40} \mathrm{Ar} /{ }^{39} \mathrm{Ar}\right.$, Walker and McDougall 1982) (Fig. 1), and the plateau age of the amphiboles in the PUB ophiolite metamorphic sole at $58 \mathrm{Ma}{ }^{40} \mathrm{Ar} /{ }^{39} \mathrm{Ar}$ (Lus et al. 2004) suggest that the volcanism at the Cape Vogel arc was short-lived, and the interval between supra-subduction lithosphere generation and ophiolite obduction was brief. Geodynamic reconstructions and studies on collision and subduction processes between the Pacific and Australian plates show that the formation of the Papuan ophiolites was possibly from early Jurassic (K-Ar age determination on gabbroic rocks gives age of $150 \mathrm{Ma}$ ) to Paleocene in age (between 65 and $60 \mathrm{Ma}$ ) (Davies and Jaques 1984; Hill and Raza 1999; Page 1976; Whattam 2009; Whattam et al. 2008). The formation age of Marum ophiolite is also not well defined and could be between $173 \mathrm{Ma}$ (K-Ar dating on plagioclase from cumulate 


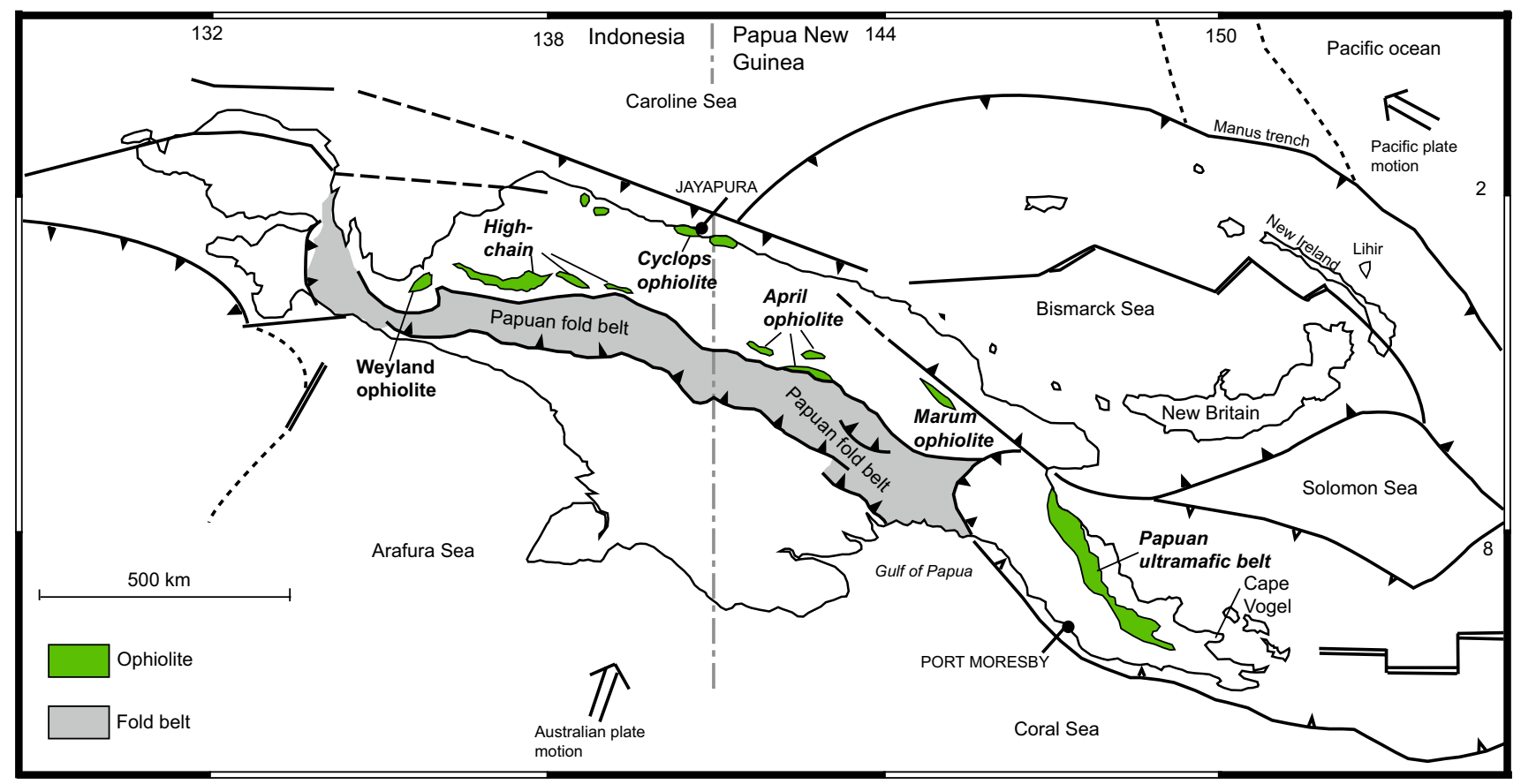

Fig. 1 Simplified sketch map of New Guinea island (after Davies 2012) showing the location of the main ophiolitic series. The grey north-south dashed line represents the border between Papua New Guinea and Indonesia

gabbros) and $59 \pm 2.5 \mathrm{Ma}(\mathrm{K}-\mathrm{Ar}$ age on hornblende from granophyric diorite for the Marum ophiolite (Jaques 1980).

\section{The Marum ophiolite}

The Marum complex and April Ultramafics are believed to have been obducted during the Paleocene and Eocene as a result of collision between the Australian continent and a Tertiary island arc (Davies 2012; Lus et al. 2004). The main structure that bounds the Marum complex to the north is the Ramu-Markham fault. The structure that bounds it to the south and separates it from the Bismarck Range is the Bundi fault zone, which is characterised by anastomosing faults, vertical strata, intense shearing and the presence of serpentinite bodies (Fig. 2).

The Marum ophiolite complex comprises two allochthons thrusted over Cretaceous to Eocene low-grade metasediments (Jaques 1980, 1981). The larger allochthon consists of a main-peridotite gabbro massif and the second, called the Tumu River Basalts, is made up essentially of basalt. The larger allochthon, subject of this study, covers an area of $1000 \mathrm{~km}^{2}$ and is 3-4 km thick (Fig. 2; Jaques $1978,1981)$. It is mainly made up of two zones: an underlying ultramafic zone (tectonite) and an overlying mafic zone (cumulate). The ultramafic tectonite at the base mainly consists of foliated harzburgite and subordinate dunite, which are cut by discordant enstatite-rich pyroxenite dykes and veins. A gradational contact is apparent between the tectonite and cumulus peridotites (Fig. 2). At the base of the cumulate section (named cumulate dunite) is a thin unit of refractory harzburgite and minor intercalated dunite plus some pegmatite gabbro and enstatite dykes. This is overlain by cumulate peridotite part that comprises lherzolite, wehrlite cumulate dunite (with minor-layered chromitite), plagioclase lherzolite, pyroxenite, and gabbro (Jaques 1980) (Fig. 2). Gabbro pegmatoid dykes and veins cut through the whole cumulate sequence, while occasional quartz dolerite dykes intrude only the top most gabbro layers.

\section{Sampling and field observations}

Our sample localities are shown on a map using GPS measurements (Fig. 2b; Table A1). The map exposes cumulate peridotite, cumulate dunite and tectonite peridotite units with gradational limits forming the classical definition of the ophiolite (Penrose, Participants 1972). However, in the Marum ophiolite the limits between units are difficult to map due to poor access to river sections and restricted access to the Ramu $\mathrm{NiCO}^{\circledR}$ Kurumbukari mine site.

The studied peridotites have been sampled in these three units, where the exposed peridotite is mostly composed of massive, coarse-grained dunite (Fig. 3). In the dunite, foliation is marked by elongation of spinel/chromite and in rare places by pyroxenitic layering (Fig. 3a-c). Strike varies between $005^{\circ}$ and $140^{\circ}$ and is dipping north-east 


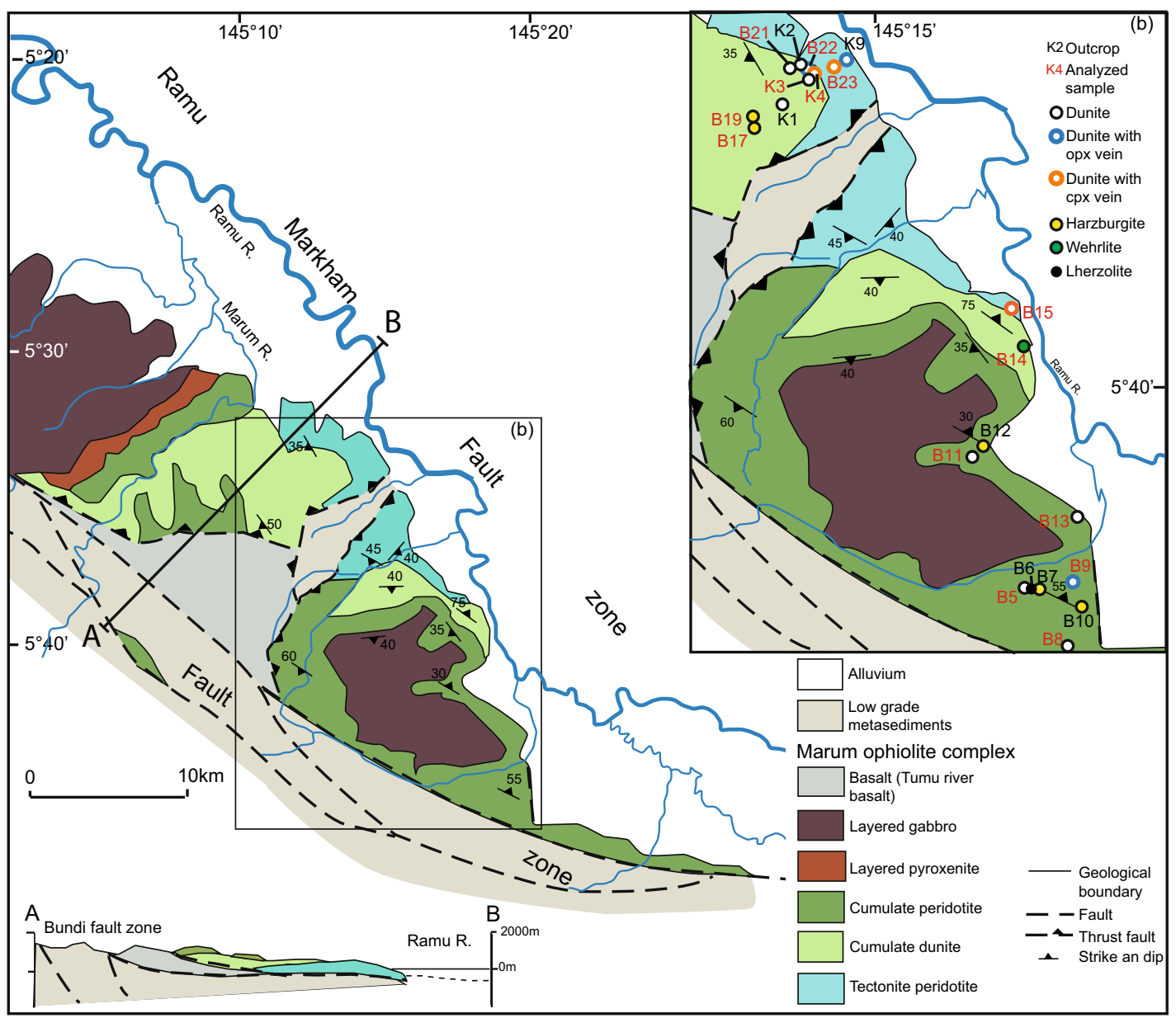

Fig. 2 a Schematic maps of the Marum ophiolite massif with ultramafic sequence and $\mathbf{b}$ closer view with visited locations and sampled outcrops (after Jaques 1978; Jaques 1981). The Marum ultramafic rocks are: Tectonite peridotite is foliated harzburgite with dunite lenses near top. Some enstatite and dunite dykes. Cumulate dunite comprises dunite, some layered chromitite, serpentinite. Gabbro pegmatite and some enstatite dykes. Cumulate peridotite: peridotite

to south-west (Fig. 2). Few harzburgite zones have been observed in the cumulate dunite area, where the contact between harzburgite and dunite is sharp and irregular at centimetre scale (Figs. 2b, 3d). The foliation and pyroxenitic layering in the dunite are cross-cut by clinopyroxenerich and orthopyroxene-rich veins (Fig. 3e). Orthopyroxene-rich veins with a thickness between 1 and $4 \mathrm{~cm}$ have discontinuous and irregular contacts with the host dunite, while larger orthopyroxene-rich veins (thickness around $8 \mathrm{~cm}$ ) have sharp contacts with the dunite (Fig. 3e, f). Outcrop $\mathrm{K} 4$ is a clinopyroxene-rich area with penetrative and discontinuous layers of clinopyroxene within the dunite (Fig. 3g). In some place the interlayered clinopyroxenerich and dunite areas form folds. These are also crosscut by newly formed orthopyroxenite veins with sharp contacts (Fig. 3c). The peridotite contains gabbro dykes mostly lherzolite, wehrlite and plagioclase lherzolite, some dunite and pyroxenite. Cumulate phases are olivine, clinopyroxene, orthopyroxene and chrome spinel; post-cumulus plagioclase. Layered pyroxenite pyroxenite, mostly websterite. Cumulate phases are clino- and orthopyroxenes, some plagioclase and olivine. Layered gabbro Noritegabbro, gabbro, norite troctolite, plagioclase pyroxenite, pyroxenite, olivine norite-gabbro, ophitic textured gabbro, dolerite dykes

ranging from 10 to $50 \mathrm{~cm}$ in width cross-cutting the peridotite and pyroxenite. The gabbro dykes can be followed for several metres and are orientated from $150^{\circ}$ to $170 / 60 \mathrm{E}$ or 040/70W. Most of the gabbros are coarse-grained anorthosite mainly composed of plagioclase and clinopyroxene with a grain size between 1 and $3 \mathrm{~cm}$ (Fig. 3h, i).

\section{Petrography}

\section{Dunite, harzburgite and wehrlite}

The dunites are coarse-grained granular ( 10 mm) and contain up to $2 \%$ clinopyroxene (Table 1 ). Olivine grains in all samples are subhedral with a slight elongation forming a shape-preferred orientation, marking the foliation (Fig. 4a). 

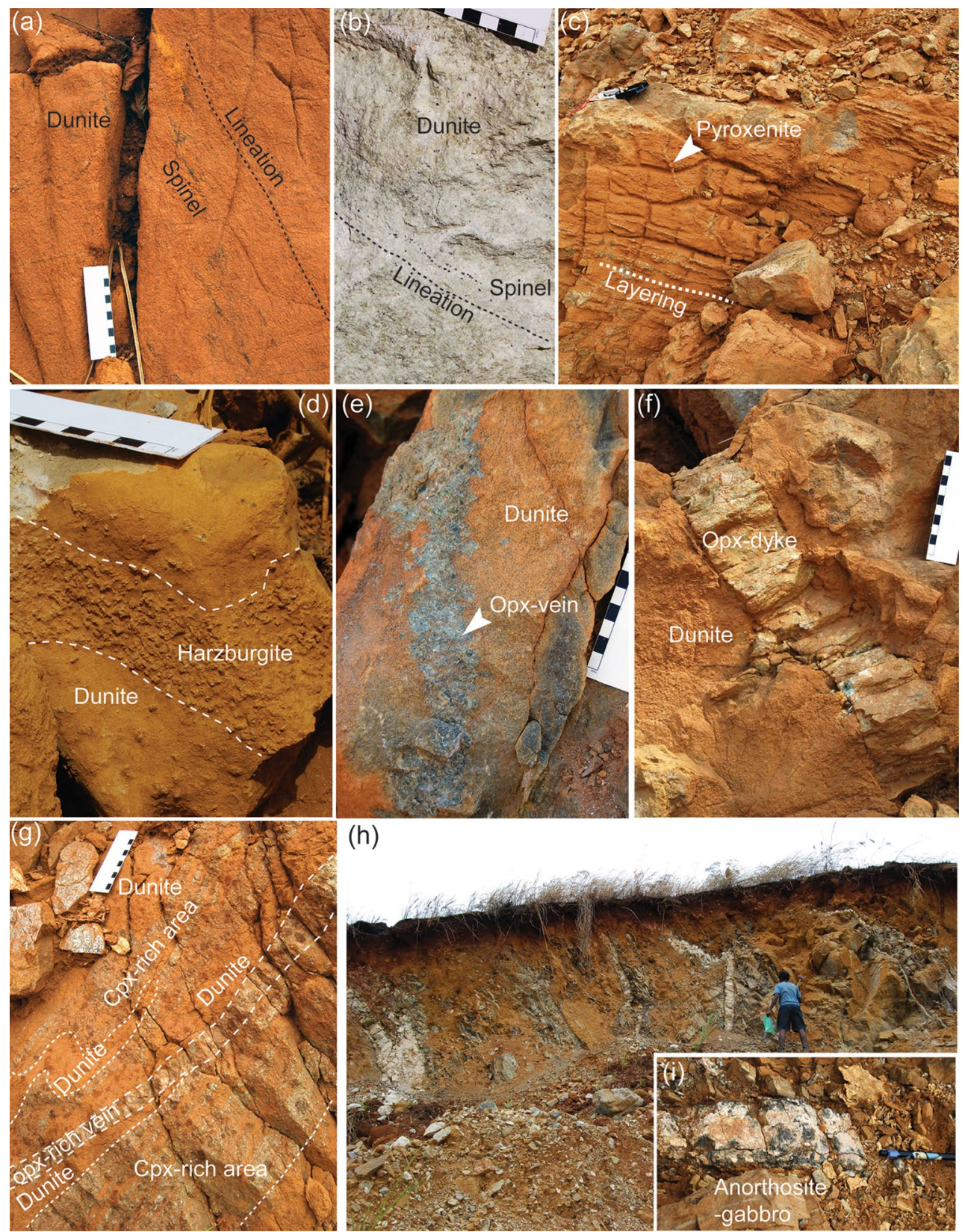

Fig. 3 Photographs of representative outcrops in the Marum ophiolite. a, b Lineation marked by spinel within dunite with superficial altered crust (a) and fresh dunite (b). c Peridotite with pyroxenitic layering defining a foliation and a small pyroxenitic vein cross-cutting the structure. d Contact between dunite and harzburgite. e Orthopyroxenite vein with diffuse contact with host dunite. $\mathbf{f}$
Orthopyroxenite vein with sharp contact to the coarse-grained dunite. $\mathbf{g}$ Intercalated dunite and clinopyroxene-rich areas cross-cut by a pyroxenite vein. h Dunite cross-cut by several anorthosite gabbroic dykes. i Detail of an anorthosite-gabbroic dyke with centimetric grain size. $O p x$ orthopyroxene, $C p x$ clinopyroxene
The olivine grain size is up to $10 \mathrm{~mm}$, with a few larger grains up to $35 \mathrm{~mm}$. Olivine grains show undulose extinction and numerous well-developed low-angle boundaries (LAB), mostly perpendicular to the foliation (Fig. 4a). Dunite B13 is characterised by a bimodal olivine grainsize distribution with large porphyroclasts up to $12 \mathrm{~mm}$ in size and olivine with grain size between 1 and $5 \mathrm{~mm}$. The rare grains of clinopyroxene in the dunites are smaller than $5 \mathrm{~mm}$ with interstitial shapes (Fig. 4b). Spinel grains display diamond-like shapes and measure between 0.1 and $1 \mathrm{~mm}$ (Fig. 4a, b). They are often located along the olivine grain boundaries or included in olivine crystals (Fig. 4a).

The harzburgites (samples B17, B19) are characterised by a granular texture formed by $80-87 \%$ olivine, $8-11 \%$ 
Table 1 Samples list with rock type, GPS location, and mineral proportions

\begin{tabular}{lllllll}
\hline Sample & Facies & \multicolumn{2}{l}{ Proportion $(\%)$} & & \\
\cline { 3 - 7 } & & Olivine & Opx & Cpx & Spinel & Plg \\
\hline K3 & Dunite & 97 & - & 2 & 1 & - \\
B5 & Dunite & 96 & - & 1 & 1 & - \\
B8 & Dunite & 90 & - & 2 & 2 & - \\
B13 & Dunite & 94 & - & 1 & 3 & - \\
B15 & Dunite & 97 & - & 1 & 2 & - \\
B21 & Dunite & 95 & - & - & 4 & - \\
B22 & Dunite & 98 & - & 1 & 1 & - \\
B14 & Wehrlite & 81 & 0.5 & 13 & 0.5 & 5 \\
B19 & Harzburgite & 87 & 11 & 0.5 & 1.5 & - \\
B17 & Harzburgite & 80 & 8 & 1 & 2 & - \\
K4 & Ol-clinopyroxenite & 10 & 4 & 86 & 1 & - \\
B23 & Ol-clinopyroxenite & 22 & 2 & 75 & 1 & - \\
B9 & Ol-websterite & 27 & 60 & 12 & 1 & - \\
K3 & Orthopyroxenite vein & - & 99 & 1 & - & - \\
B22 & Orthopyroxenite vein & - & 99 & 1 & - & - \\
B14 & Gabbroic vein & 5 & 34 & 33 & - & 27 \\
\hline
\end{tabular}

Mineral proportions are estimated using optical microscope and compared with those obtained by EBSD mapping

orthopyroxene, $0.5-1 \%$ clinopyroxene, and $1.5-2 \%$ spinel (Fig. 4c; Table 1). The olivine crystals display irregular shapes up to $6 \mathrm{~mm}$ in size and LAB. Large olivine crystals are elongated parallel to lineation with aspect ratio around 2:1. The clinopyroxene is smaller than $0.1 \mathrm{~mm}$. The orthopyroxene is randomly distributed and measures between 0.5 and $3 \mathrm{~mm}$ (Fig. 4c). Larger grains contain thin exsolution lamellae of clinopyroxene, and smaller grains display interstitial shapes without exsolution (Fig. 4d). Spinel is similar to those in the dunite with diamond-like shape and grain size up to $1 \mathrm{~mm}$. The crystals are distributed within olivine large crystals or along olivine grain boundaries (Fig. 4c).

The fine-grained granular wehrlite (sample B14) contains $81 \%$ olivine, $13 \%$ clinopyroxene, $0.5 \%$ orthopyroxene, $5 \%$ plagioclase and $0.5 \%$ spinel (Fig. 4e). The olivine has subhedral shape with grain size ranging between 0.5 and $3 \mathrm{~mm}$ and some larger elongated grains up to $4 \mathrm{~mm}$ with aspect ratio of 1.5:1. Large olivine crystals display LAB. The clinopyroxene displays interstitial shape with a grain size up to $1 \mathrm{~mm}$ (Fig. 4f). The wehrlite contains plagioclase (Fig. 4f), with a grain size up to $0.5 \mathrm{~mm}$ and spinel randomly distributed in the sample with anhedral or diamond-like shapes (Fig. 4f). A centimetric gabbroic vein cut across the wehrlite with diffuse contacts (Fig. 4e) and is composed of large grains of orthopyroxene, clinopyroxene and plagioclase (up to $7 \mathrm{~mm}$ ). Orthopyroxene in the gabbroic vein shows thin exsolution lamellae of clinopyroxene and clinopyroxene contains thin exsolution lamellae of orthopyroxene (Fig. 4e).

\section{Ol-clinopyroxenite}

Sample B23 is an ol-clinopyroxenite vein with a porphyroclastic texture and comprises $75 \%$ clinopyroxene, $22 \%$ olivine $4 \%$ orthopyroxene, and $1 \%$ spinel (Table 1; Fig. 4g). The large clinopyroxene grains are anhedral, measures between 1 and $5 \mathrm{~mm}$ and contain thin exsolution lamellae of orthopyroxene. The "matrix" comprises olivine, orthopyroxene and clinopyroxene, where olivine forms aggregates with a long shape parallel to the foliation (Fig. 4g). Olivine has subhedral shape with grain size up to $0.15 \mathrm{~mm}$ and LAB perpendicular to the foliation. In the matrix, clinopyroxene and orthopyroxene have anhedral shape with a grain size up to $0.5 \mathrm{~mm}$. Spinel grains are anhedral, with a grain size between 0.05 and $0.1 \mathrm{~mm}$ and occur on grain boundaries.

Sample K4 is an ol-clinopyroxenite containing $10 \%$ olivine, $4 \%$ orthopyroxene, $86 \%$ clinopyroxene and $1 \%$ spinel with a granular texture (Fig. $5 \mathrm{~h}$ ). The sample is part of a clinopyroxenite-rich area illustrated in Fig. 3g. Olivine grains are anhedral with grain size varying between 0.5 and $45 \mathrm{~mm}$. Some of the large olivine grains have undulose extinctions or formation of LAB. Clinopyroxene grains are anhedral, inequigranular with a grain size from 6.6 to $0.5 \mathrm{~mm}$, and show numerous thin exsolution lamellae of orthopyroxene. Orthopyroxene is present only near the clinopyroxene and has a grain size up to $2 \mathrm{~mm}$ with anhedral shape. The spinel grains occur on grain boundaries, have irregular shape, and measure between 0.05 and $0.1 \mathrm{~mm}$. 
Fig. 4 Photomicrographs and backscatter images of Marum peridotites. a Granular texture in dunite (sample K3) where foliation is noted as dashed line (crossed polars). Olivine displays numerous LAB mostly perpendicular to the foliation. $\mathbf{b}$ Backscatter image of interstitial clinopyroxene and orthopyroxene in a dunite (sample B13). c Granular harzburgite (sample B19, crossed polars). The dashed line underlines the foliation. $\mathbf{d}$ Backscatter image of interstitial orthopyroxene in the harzburgite. $\mathbf{e}$ Wehrlite (sample B14, crossed polars) containing a centimetric gabbroic vein. Note that plagioclase is also present in the wehrlite (f, backscatter image). g Ol-clinopyroxenite (sample B23, crossed polars). The dashed line represents the foliation. The clinopyroxenes have larger grain size than olivine. h Ol-clinopyroxenite (sample K4, crossed polars). i Dunite with a centimetric orthopyroxenite vein (sample $\mathrm{K} 3$, crossed polars). j Olwebsterite (sample B9, crossed polars). The orthopyroxenes show thin exsolution lamellae, undulose extinction and some have LAB. The clinopyroxene is heterogeneously distributed in the sample with a higher proportion in part $A$ than in part $B$. The dashed line represents the foliation and separates parts A and B. Opx orthopyroxene, Cpx clinopyroxene, $\mathrm{Ol}$ olivine, $S p$ spinel, $P l$ plagioclase (a) Dunite (K3)

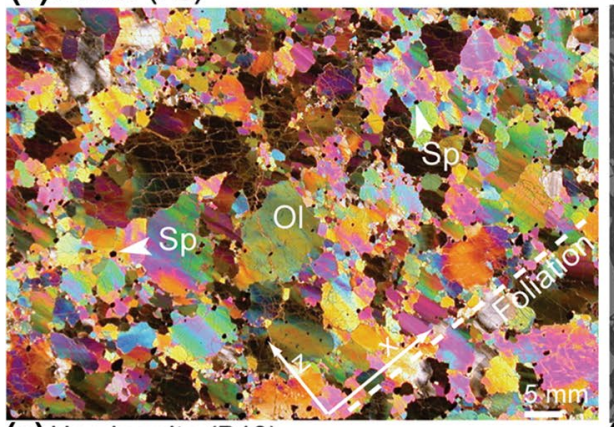

(c) Harzburgite (B19)

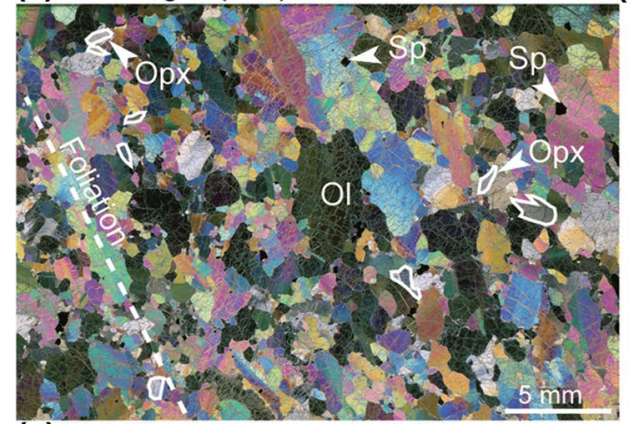

(e) Wehrlite + gabbroic vein (B14)

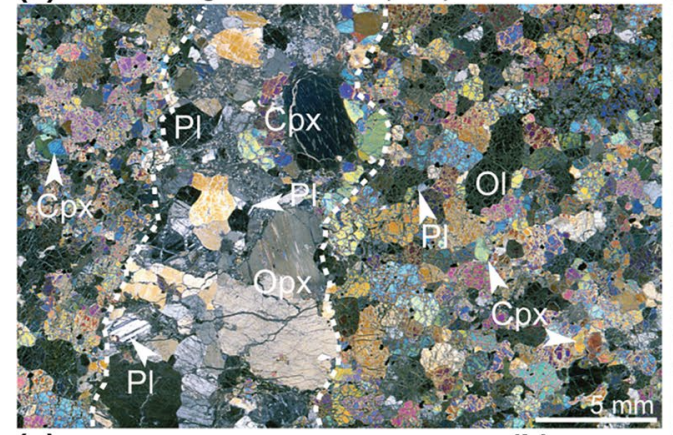

(b)Dunite (B13)

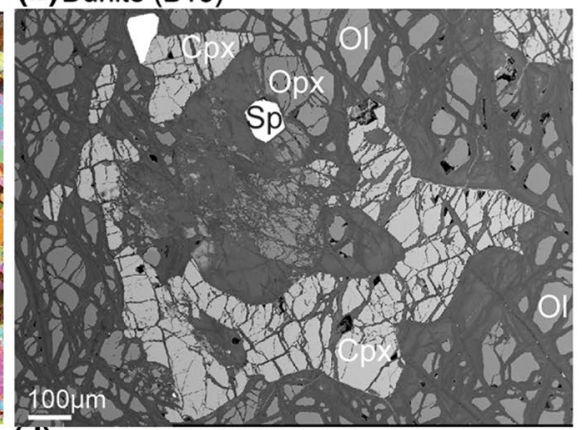

(d) Harzburgite (B19)

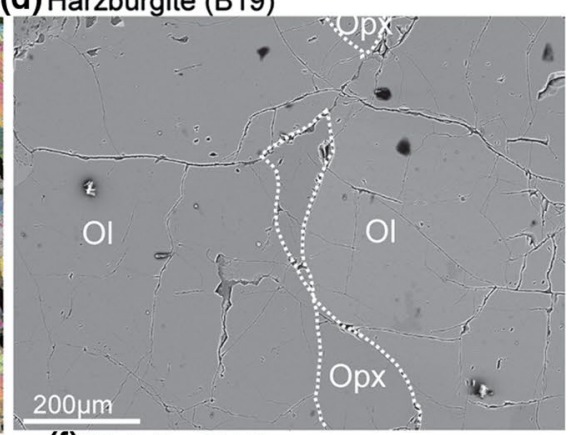

(f) Wehrlite (B14)

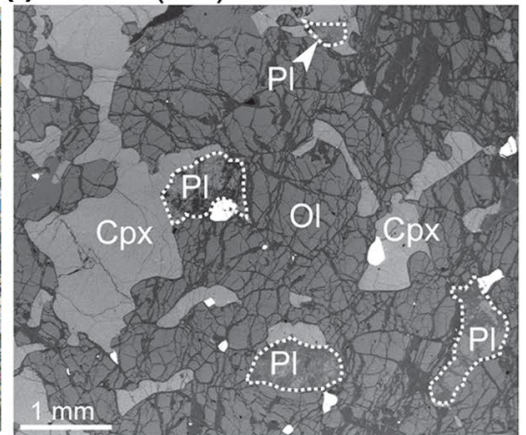

(g)Ol-clinopyroxenite (B23)

(h) Ol-clinopyroxenite (K4)

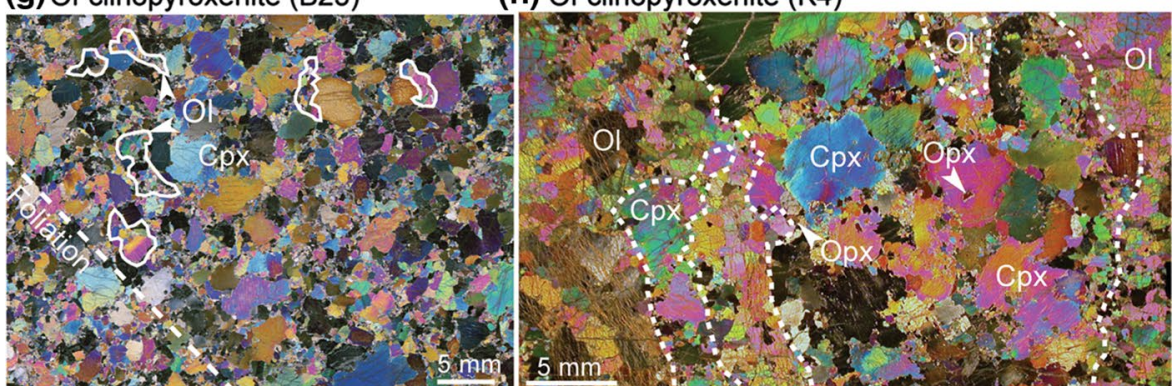

(i) Dunite / orthopyroxenite vein (K3)

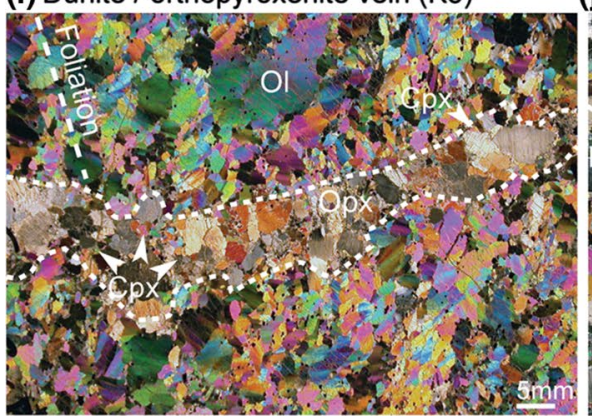

(j)Ol-websterite (B9)

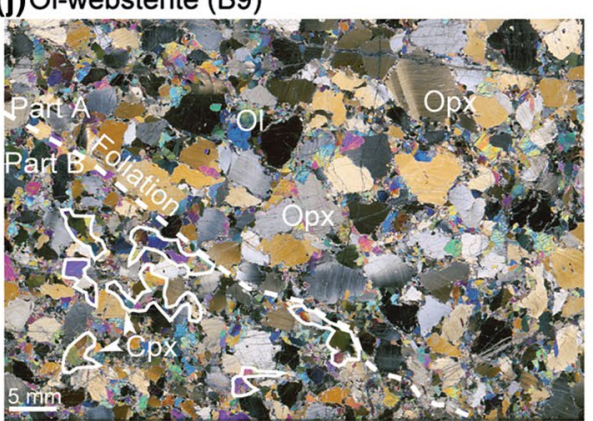


Fig. 5 Major elements composition of olivine, clinopyroxene, orthopyroxene and spinel from peridotite and pyroxenite from Marum ophiolite. Data on Marum peridotite from Jaques (1980, 1981). Cyclops and High-Chain ophiolites are reported for comparison (Monnier 1996). a Olivine $\mathrm{NiO}$ (wt\%) versus Mg\#. Average Mg\# from Jaques (1980) is reported for cumulate peridotite and cumulate dunite as dashed lines for a $\mathrm{NiO}$ content lower than $0.15 \mathrm{wt} \%$ (the detection limit); b clinopyroxene $\mathrm{TiO}_{2}$ versus $\mathrm{Al}_{2} \mathrm{O}_{3}$ (wt $\%$ ). c Orthopyroxene $\mathrm{Al}_{2} \mathrm{O}_{3}$ (wt\%) versus $\mathrm{Mg \#}$; (d) Chromite and spinel $\mathrm{Cr} \#$ versus $\mathrm{Mg} \#$

\section{Orthopyroxenite veins and ol-websterite}

Dunite K3 and B22 contain a 1-cm-thick orthopyroxenite vein formed by $99 \%$ orthopyroxene and $1 \%$ clinopyroxene (Fig. 4i; Table 2). The contact between the two lithologies appears to be diffuse in the thin section (Figs. 3e, 4i). The orthopyroxene ranges in size from 8 to $10 \mathrm{~mm}$, is subhedral, shows numerous thin exsolution lamellae of clinopyroxene, and sometimes undulose extinction. Clinopyroxene has a grain size smaller than $1 \mathrm{~mm}$ and is distributed randomly in the vein (Fig. 4i).

Sample B9, an ol-websterite, comprises orthopyroxene $60 \%$, olivine $27 \%$, clinopyroxene $12 \%$, and spinel $1 \%$ (Table 2; Fig. 4j). The orthopyroxene is subhedral and has a grain size between 1 and $8 \mathrm{~mm}$. It contains numerous exsolution lamellae of clinopyroxene and show undulose extinction and sometimes LAB (Fig. 4j). There are no smaller orthopyroxene grains around large grains. The olivine grains are anhedral with a grain size varying between 0.3 and $1 \mathrm{~mm}$. The clinopyroxene is anhedral with a grain size up to $3 \mathrm{~mm}$ and is heterogeneously distributed in the sample with $5 \%$ in the main part (part A) and $28 \%$ in the rest of the thin section (part B below the dashed line on Fig. $4 \mathrm{j}$ following the foliation). The clinopyroxene forms aggregates generally parallel to the foliation. In part $\mathrm{B}$, the orthopyroxene grain size is smaller (up to $5 \mathrm{~mm}$ ) than in the rest of the sample.

\section{Mineral composition}

\section{Analytical procedures}

Major elements in minerals were analysed by electron microprobe using the CAMECA-SX100 available at the Microsonde Sud facility (Université de Montpellier II) equipped with five wavelength-dispersive spectrometers and using the JEOL8200 superprobe at the University of Lausanne. Twelve samples were analysed: seven dunites of which two contain centimetric orthopyroxenite vein, one wehrlite containing a centimetric gabbroic dyke, one harzburgite, two ol-clinopyroxenite, and one ol-websterite
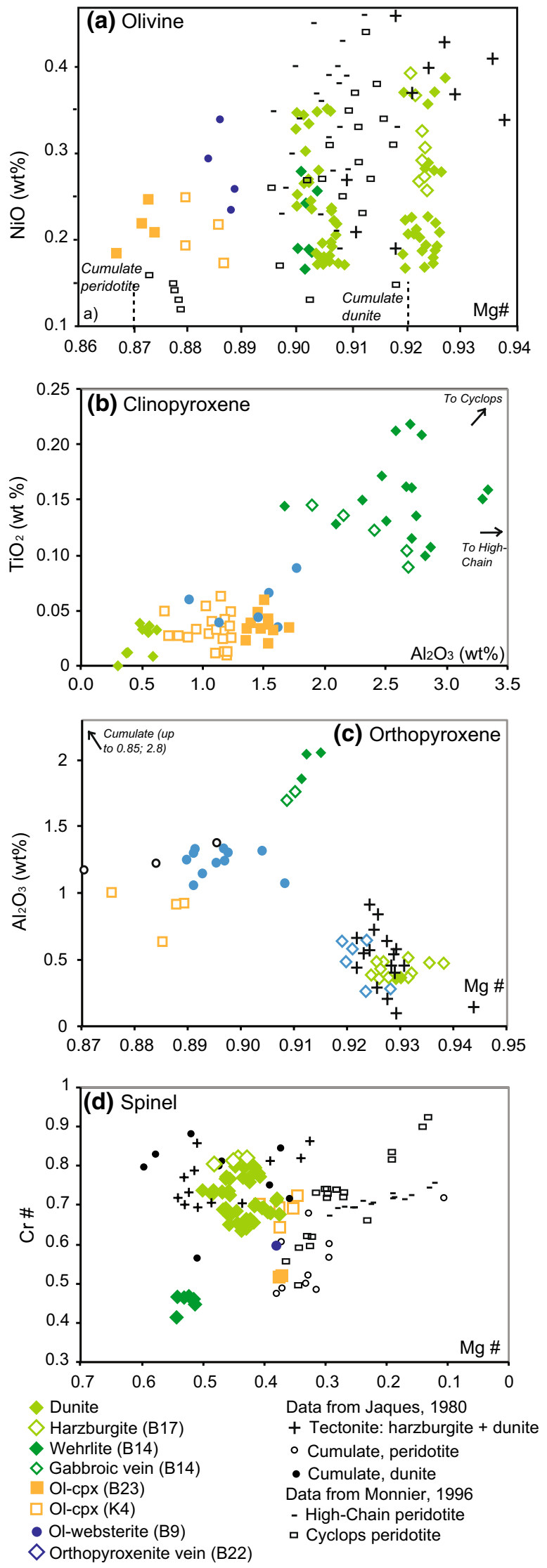
Table 2 Thermometry of Marum peridotites based on coexisting pyroxenes and olivine-spinel equilibrium

\begin{tabular}{|c|c|c|c|c|c|c|c|c|}
\hline Samples & Thermometers & $\mathrm{Opx}_{\mathrm{BK} 90}$ & $\mathrm{Opx}_{\mathrm{WS} 91}$ & $n$ & $2 \operatorname{Prx}_{\mathrm{BK} 90}$ & $n$ & $\mathrm{Ol}-\mathrm{Sp}_{\mathrm{Bal} 91}$ & $n$ \\
\hline B8 & Dunite & - & - & & - & & $\mathrm{X}$ & 4 \\
\hline B13 & Dunite & $969 \pm 28$ & $\mathrm{X}$ & 2 & - & & $\mathrm{X}$ & 3 \\
\hline B15 & Dunite & - & - & & - & & & \\
\hline B21 & Dunite & - & - & & - & & $915 \pm 54$ & 5 \\
\hline B22 & Dunite & - & - & & - & & $\mathrm{X}$ & 5 \\
\hline B14 & Wehrlite & $969 \pm 54$ & $\mathrm{X}$ & 4 & $763 \pm 35$ & 3 & $\mathrm{X}$ & 3 \\
\hline B17 & Harzburgite & $899 \pm 9$ & $\mathrm{X}$ & 12 & - & & $\mathrm{X}$ & 4 \\
\hline B23 & Ol-clinopyroxenite & - & - & & - & & $\mathrm{X}$ & 4 \\
\hline K4 & Ol-clinopyroxenite & $963 \pm 67$ & $829 \pm 44$ & 4 & - & & $X$ & 4 \\
\hline B9 & Ol-websterite & $1059 \pm 129$ & $820 \pm 31$ & 9 & $777 \pm 23$ & 5 & $X$ & 2 \\
\hline B22 & Orthopyroxenite vein & $845 \pm 13$ & $\mathrm{X}$ & 4 & - & & - & \\
\hline B14 & Gabbroic vein & $933 \pm 54$ & $\mathrm{X}$ & 3 & $804 \pm 63$ & 3 & - & \\
\hline
\end{tabular}

The temperatures are calculating for 2-12 neighbouring grains $(n)$

OpxWS91: Witt-Eickschen and Seck (1991); OpxBK90 and 2PrxBK90: Brey and Köhler (1990); OlSpBa191: Ballhaus et al. 1991. X represents samples where thermometer cannot be applied: see text for explanation
(Table A2). For both electron microprobes, operating conditions comprised an acceleration voltage of $15 \mathrm{kV}$ and a $10 \mathrm{nA}$ beam current. $\mathrm{K}$ and $\mathrm{Na}$ were counted for $20 \mathrm{~s}$ with a $10 \mathrm{~s}$ background, and the other elements were counted for $30 \mathrm{~s}$ with a $15 \mathrm{~s}$ background. Natural and synthetic oxides were used as standards. Averages of mineral compositions and their standard deviations are listed in Table A2.

Trace element analyses on minerals of six samples (Table A3) were performed by laser ablation inductively coupled plasma mass spectrometry (LA-ICP-MS) at the Institute of Earth Sciences, University of Lausanne (Switzerland). We used a pulsed $193 \mathrm{~nm}$ Excimer Laser system $\left(\right.$ Geolas $\left.^{\circledR}\right)$, coupled with Perkin-Elmer ELAN 6100 DRC ICP-MS system. Operating conditions of the laser were $20 \mathrm{~Hz}$ repetition rate, yielding a flux of ca $4.5 \mathrm{~J} / \mathrm{cm}^{2}$ on the ablation site and 75-120 $\mu \mathrm{m}$ spot size. Helium was used as a carrier gas. The SRM612 NIST glass was chosen as an external standard (Jochum et al. 2011) and $\mathrm{SiO}_{2}$ as the internal standards. Raw data were reduced off-line using the LAMTRACE software (Jackson 2008).

\section{Major elements}

Olivine from dunite, wehrlite and harzburgite samples has homogeneous composition from core to rim, and is depleted with an $\mathrm{Mg \#}$ [molar $\mathrm{Mg} /(\mathrm{Mg}+\mathrm{FeTot})]$ varying between 0.90 and 0.93 (Fig. 5a; Table A2). Olivine Mg\# and spinel $\mathrm{Cr} \#$ [molar $\mathrm{Cr} /(\mathrm{Cr}+\mathrm{Al})]$ point out two groups of dunites. However, these compositions are not linked to their structural position in the ophiolitic sequence (Figs. 2b, 5a). For instance, olivine from dunites K3 and B23 plots in the high Mg\# group, while dunite B22 has lower Mg\#, but all have been sampled in the same area (Fig. 2b). All these compositions encompass the olivine $\mathrm{Mg \#}$ from cumulate dunite and tectonite analysed by Jaques (1980). Olivine in lherzolite and harzburgite from the High-Chain ophiolite (Fig. 1) has a composition similar to Marum olivine in the 0.90-0.92 Mg\# range (no highly depleted composition) (Monnier 1996). In the Marum peridotites, the olivine with the lowest $\mathrm{Mg \#}$ content $(<0.89)$ and the highest $\mathrm{FeO}$ and $\mathrm{MnO}$ contents is from ol-clinopyroxenite (samples $\mathrm{K} 4$ and B23), and ol-websterite (sample B9) (Fig. 5a) and has similar $\mathrm{Mg \#}$ to olivine from cumulate peridotite analyses from Jaques (1980), and cpx-dunite $(\mathrm{Mg \#} \mathrm{<} \mathrm{0.88)} \mathrm{from}$ Cyclops ophiolite (Monnier 1996). Olivine $\mathrm{NiO}$ content varies between 0.15 and $0.40 \mathrm{wt} \%$, with the highest content observed in the harzburgite (sample B17, Fig. 5a). These values encompass those from slow-spreading ridge spinel peridotite (0.23-0.44 wt\%, Dick 1989).

Clinopyroxenes in dunite have low $\mathrm{Al}_{2} \mathrm{O}_{3}(0.29-0.58$ wt $\%)$ and $\mathrm{TiO}_{2}(0.008-0.032 \mathrm{wt} \%)$ contents, and high $\mathrm{Na}_{2} \mathrm{O}$ content $(0.01-0.39 \mathrm{wt} \%)$, and $\mathrm{Cr} \#(>0.49)$ (Fig. 5b; Table A2). This high Cr\# in clinopyroxene is also observed in the tectonite area studied by Jaques (1980) varying from 0.40 to 0.66 in the harzburgite. The clinopyroxene from the ol-clinopyroxenite (samples B23, K4) and the ol-websterite (sample B9) displays similar $\mathrm{Al}_{2} \mathrm{O}_{3}$ content varying between 0.69 and $1.70 \mathrm{wt} \%$ and $\mathrm{TiO}_{2}$ content $(0.01-0.09$ wt\%) (Table A2). The Cr\# compositions are similar to clinopyroxene from the cumulate area (Jaques 1980, 1981). Clinopyroxene from the wehrlite and gabbroic vein (sample B14) has high $\mathrm{TiO}_{2}(0.10-0.22 \mathrm{wt} \%), \mathrm{Al}_{2} \mathrm{O}_{3}$ (between 1.66 and $3.32 \mathrm{wt} \%)$ and $\mathrm{Na}_{2} \mathrm{O}(0.22-0.46 \mathrm{wt} \%)$ contents for a low $\mathrm{Cr} \#(<0.21)$. Clinopyroxene from High-Chain ophiolite (Indonesian part) is enriched in $\mathrm{Al}_{2} \mathrm{O}_{3}(>2.6 \mathrm{wt} \%$ ) for similar $\mathrm{TiO}_{2}$ in the wehrlite, while clinopyroxene in 
Cyclops ophiolite has both higher $\mathrm{TiO}_{2}(>0.32 \mathrm{wt} \%)$ and higher $\mathrm{Al}_{2} \mathrm{O}_{3}$ content (Monnier 1996).

The harzburgite (sample B17), a dunite (sample B13) and the orthopyroxenite vein (in dunite B22) contain orthopyroxene with high $\mathrm{Mg \#}(0.92-0.94)$ and low $\mathrm{Al}_{2} \mathrm{O}_{3}$ content varying between 0.27 and $0.65 \mathrm{wt} \%$ (Fig. 5c). This range of composition encompasses orthopyroxene composition from the tectonite part defined by Jaques (1980). The orthopyroxene in the wehrlite has the highest $\mathrm{Al}_{2} \mathrm{O}_{3}$ content $(1.69-2.05 \mathrm{wt} \%)$ for an intermediate $\mathrm{Mg} \#(\approx 0.91$, Fig. $5 \mathrm{c})$. Orthopyroxene from ol-clinopyroxenite and ol-websterite has a $\mathrm{Mg} \#<0.91$, and an intermediate $\mathrm{Al}_{2} \mathrm{O}_{3}(0.6-1.37$ $\mathrm{wt} \%$ ) (Table A2), composition similar to orthopyroxene from the cumulate part defined by Jaques $(1980,1981)$.

Spinel in the dunite and harzburgite displays a large variation in $\mathrm{TiO}_{2}$ and $\mathrm{Mg \#}$, with the highest $\mathrm{Cr} \#$ in the harzburgite (Table A2; Fig. 5d). High Cr\# composition plots in the field of spinel from tectonite and cumulate dunite areas (Jaques 1980; Fig. 5d). Ol-clinopyroxenite and ol-websterite contain spinel with lower $\mathrm{Cr} \#$ and higher $\mathrm{Mg \#}$ than most dunite. Only the wehrlite (sample B14) contains spinel with high $\mathrm{Mg \#}(0.52-0.54)$ and low $\mathrm{Cr} \#(<0.47)$ (Fig. 5d). The spinel from Cyclops and High-Chain ophiolites has a lower Mg\# (up to 0.3) than Marum spinel for similar Cr\# (Monnier 1996) (Fig. 5b).

Plagioclase analyses were performed only on the wehrlite (sample B14) and showed composition around $\mathrm{An}_{91}$ (Table A2). There is no chemical variation between plagioclase in the wehrlite and the gabbroic vein.

\section{Trace elements}

The chondrite-normalised rare earth element (REE) patterns of clinopyroxenes in ol-clinopyroxenite and olwebsterite have flat-shape pattern from Middle(M)REE to $\operatorname{High}(\mathrm{H}) \mathrm{REE}\left(\mathrm{Gd}_{\mathrm{N}} / \mathrm{Lu}_{\mathrm{N}} 1.0-1.3\right)$ and are depleted in Light(L)REE $\left(\mathrm{La}_{N}\right.$ 0.10-0.23) (Fig. 6a; Table A3). They are enriched in LREE to MREE compared to SSZ clinopyroxenes (Parkinson et al. 1992). Clinopyroxenes in the wehrlite and associated centimetric gabbroic vein have similar shape patterns, but are REE enriched $\left(\mathrm{La}_{N} / \mathrm{Lu}_{\mathrm{N}} 0.07\right.$ and $\mathrm{La}_{\mathrm{N}} / \mathrm{Lu}_{\mathrm{N}} 0.08$, respectively) compared to other clinopyroxenes from the Marum peridotite $\left(\mathrm{La}_{\mathrm{N}} / \mathrm{Lu}_{\mathrm{N}} 0.17-0.45\right.$, Fig. 6a; Table A3). They plot within the abyssal peridotite field (Johnson and Dick 1992; Johnson et al. 1990).

All orthopyroxenes display typical REE patterns with high depletion in LREE $\left(\mathrm{Ce}_{\mathrm{N}} / \mathrm{Yb}_{\mathrm{N}} 0.02-0.03\right.$ and 0.003 in the wehrlite) (Fig. 6b; Table A3). Marum orthopyroxenes have typical REE patterns, while they have more depleted composition than orthopyroxenes from oceanic mantle (e.g. Kaczmarek and Müntener 2010), and similar to or more depleted than orthopyroxene from SSZ (Ionov 2010; Jean et al. 2010; Le Roux et al. 2014). Orthopyroxene from the
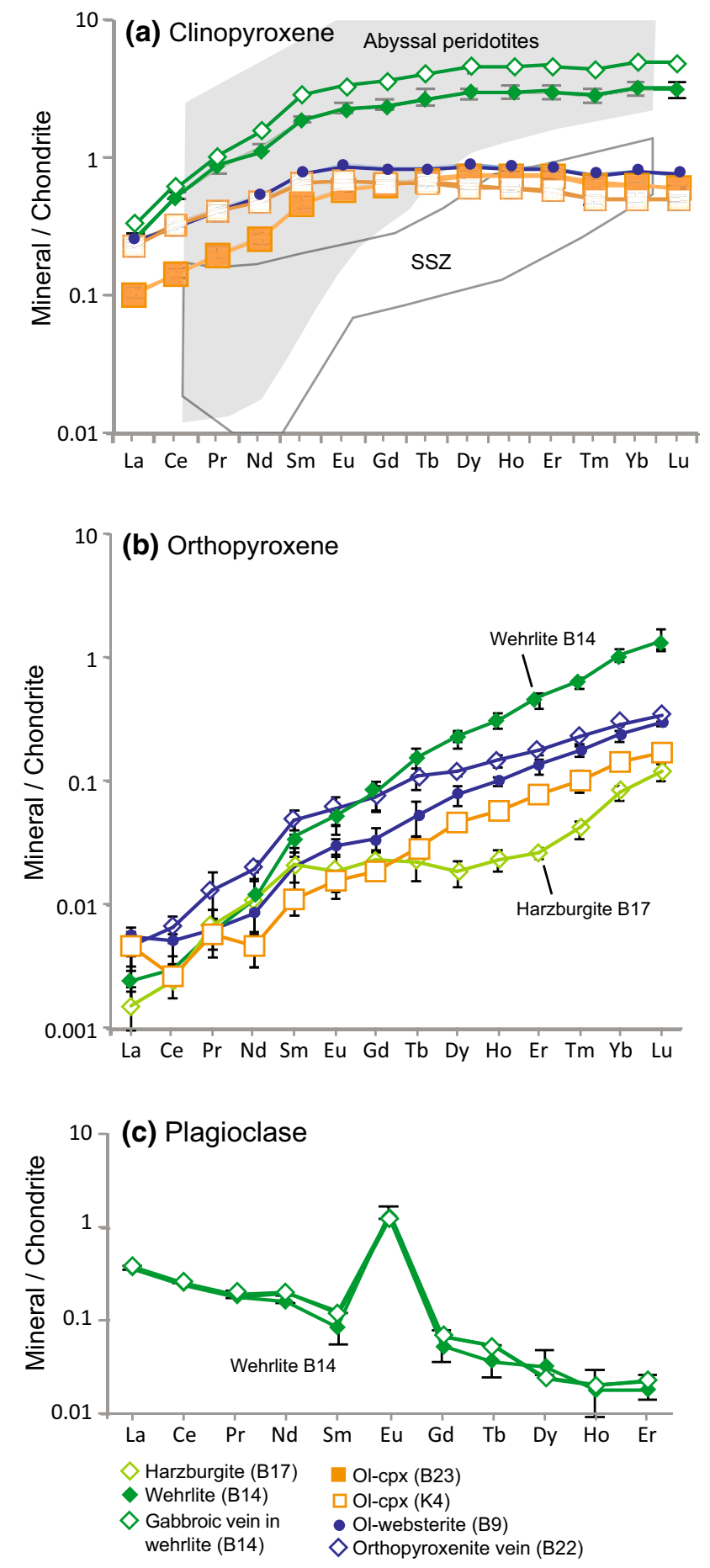

Fig. 6 Trace elements normalised to chondrite (McDonough and Sun 1995) of a clinopyroxene, b orthopyroxene and $\mathbf{c}$ plagioclase from Marum peridotites. Supra-subduction zone (SSZ) clinopyroxenes field is from Parkinson et al. (1992) and clinopyroxenes from abyssal peridotites are from Johnson et al. (1990) and Johnson and Dick (1992)

harzburgite is slightly depleted in HREE compared to other orthopyroxenes and is similar in composition to orthopyroxene from Josephine ophiolite harzburgite (Le Roux et al. 
2014) (Fig. 6b). Orthopyroxene from the wehrlite (sample B14) is enriched in MREE to HREE relative to other peridotites $\left(\mathrm{Gd}_{\mathrm{N}} / \mathrm{Lu}_{\mathrm{N}}\right.$ 0.06). A slight progressive enrichment is observed within the MREE-HREE segment from harzburgite $\left(\mathrm{Gd}_{\mathrm{N}} / \mathrm{Lu}_{\mathrm{N}} 0.19\right)$, to ol-clinopyroxenite, ol-websterite, and orthopyroxenite veins $\left(\mathrm{Gd}_{\mathrm{N}} / \mathrm{Lu}_{\mathrm{N}} 0.11-0.21\right)$, and finally wehrlite $\left(\mathrm{Gd}_{\mathrm{N}} / \mathrm{Lu}_{\mathrm{N}} 0.05\right)$ (Fig. $\left.6 \mathrm{~b}\right)$.

Plagioclase from wehrlite has low HREE content $\left(\mathrm{Er}_{\mathrm{N}}\right.$ 0.2) and LREE-enriched patterns with large positive Eu anomaly $\left[\mathrm{Eu} / \mathrm{Eu}^{*}=\mathrm{Eu}_{\mathrm{N}} /\left(\mathrm{Sm}_{\mathrm{N}}+\mathrm{Gd}_{\mathrm{N}}\right) / 2\right]$ from 5.4 to 3.4 in matrix and gabbroic vein, respectively (Fig. 6c; Table A3).

\section{Thermometry}

Temperatures have been estimated for orthopyroxene using Witt-Eickschen and Seck (1991) thermometer based on $\mathrm{Al}$ and $\mathrm{Cr}$ contents $\left(\mathrm{Opx}_{\mathrm{WS} 91}\right)$, Brey and Köhler (1990) thermometer $\left(\mathrm{Opx}_{\mathrm{BK} 90}\right)$ based on Ca contents in opx, twopyroxenes Brey and Köhler (1990) thermometer $\left(2 \operatorname{Prx}_{\mathrm{BK} 90}\right)$ based on $\mathrm{Fe}-\mathrm{Mg}$ exchange, and olivine-spinel thermometer $\left(\mathrm{Ol}-\mathrm{Sp}_{\mathrm{Ba} 91}\right)$ based on $\mathrm{Fe}^{2+}-\mathrm{Mg}$ exchange (Ballhaus et al. 1991) (Table 2). These thermometers have been applied at a pressure assumed to be $1.5 \mathrm{GPa}$, implying equilibration in the spinel stability field and a pressure of $1 \mathrm{GPa}$ for the wehrlite (Sample B14), implying equilibration in the plagioclase stability field. Application of the $\mathrm{Opx}_{\mathrm{BK} 90}$ thermometer in dunite and harzburgite indicates temperatures varying between $899 \pm 9$ and $969 \pm 28{ }^{\circ} \mathrm{C}$ (Table 2). The wehrlite has lower temperature $\left(763 \pm 35{ }^{\circ} \mathrm{C}\right)$ than dunite using $2 \mathrm{Prx}_{\mathrm{BK} 90}$ thermometer. The Ol-Sp $\mathrm{Ba}_{\mathrm{Ba} 91}$ thermometer gave reasonable results to temperature higher than $800{ }^{\circ} \mathrm{C}$ for spinel peridotites (Ballhaus et al. 1991), and only dunite B21 gave a temperature higher than $800{ }^{\circ} \mathrm{C}\left(915 \pm 54{ }^{\circ} \mathrm{C}\right)$ falling in the range of temperature obtained with pyroxenes thermometers (Table 2). The $\mathrm{Opx}_{\mathrm{WS} 91}$ thermometer has only been applied on ol-clinopyroxenite and ol-websterite, because other orthopyroxenes fell outside the compositional range allowed for the "Cr-Al-opx" thermometer as defined by Witt-Eickschen and Seck (1991). The temperature calculated is similar in both samples and gives an average of $824 \pm 6{ }^{\circ} \mathrm{C}$. The ol-websterite records high temperature with a large error using $\mathrm{Opx}_{\mathrm{BK} 90}$ thermometer $\left(1059 \pm 129^{\circ} \mathrm{C}\right.$ ), which is related to high Ca contents (up to $1.75 \mathrm{wt} \%$ ) in some of the orthopyroxenes.

\section{Crystal preferred orientation}

\section{Analytical procedures}

The electron backscatter secondary diffraction (EBSD) method was used to analyse microstructure (Adams et al.
1993), and olivine and pyroxene CPOs were measured in 10 samples. Samples were cut perpendicular to the foliation and parallel to the lineation (XZ sections) within the peridotite. CPO was measured by indexing EBSD patterns using the JEOL JSM 5600 SEM-EBSD system at Géosciences Montpellier. Collection, indexing and analysis of electron backscatter diffraction patterns (EBSP) were done using the CHANNEL 5.10 software by Oxford Instruments. Crystallographic orientation maps (usually $20 \times 35 \mathrm{~mm}$ ) were obtained by collecting EBSPs over a regular grid step ranging from 35 to $55 \mu \mathrm{m}$ depending on the mean grain size of the sample. The percentage of successful indexing was $\sim 70 \%$. The EBSD data were noise reduced using a standard procedure (Bestmann and Prior 2003; Prior et al. 2002). At each of these steps, the resulting orientation maps were compared with band contrast maps to ensure that the noise reduction did not compromise the data by, for instance, changing the shape of the minerals.

Pole figures of crystallographic orientation of olivine, clinopyroxene and orthopyroxene are plotted using the Oxford CHANNEL 5.10 software in Figs. 7, 8 and A1, A2. Data are plotted using lower hemisphere, equal area projections. Pole figures are represented using average Euler angles for one point per grain to avoid over-representation of large grains on thin sections. Measuring CPOs of minerals is a common method to infer the activated slip systems of a mineral. In this case the preferred orientation of crystallographic axes parallel to the lineation and normal to the foliation corresponds to the slip direction and slip plane, respectively. The contours of multiples of uniform density (mud) is used to describe the sharpness and strength of a pole figure for each given crystallographic axes. $J$-index was calculated to quantify CPO strength (Bunge 1982) using D. Mainprice software (CareWare UNICEF programs). The value varies from 1 for random distribution, whereas the maximum value is dependent on crystal symmetry and symmetry of the crystal axis (Ben Ismail and Mainprice 1998; Michibayashi et al. 2006; Tommasi et al. 2000).

The analyses of crystallographic axes orientation at bulk rock scale, combined with foliation and lineation and the geometrical relationship between subgrain boundaries and rotation axes based on EBSD mapping, are used to infer the activated slips (example shown in Fig. 9) (e.g. Boyle et al. 1998; Kaczmarek and Reddy 2013; Lloyd et al. 1997; Prior et al. 1999, 2002; Reddy et al. 2007).

\section{Dunite, harzburgite and wehrlite}

The Marum peridotites display a well-developed olivine CPO with $<100>$ axes describing a strong concentration parallel to the lineation $X$ (Figs. 7, 8, 9, A1, A2). The olivine $J$-index is high in dunite varying between 11.2 and 


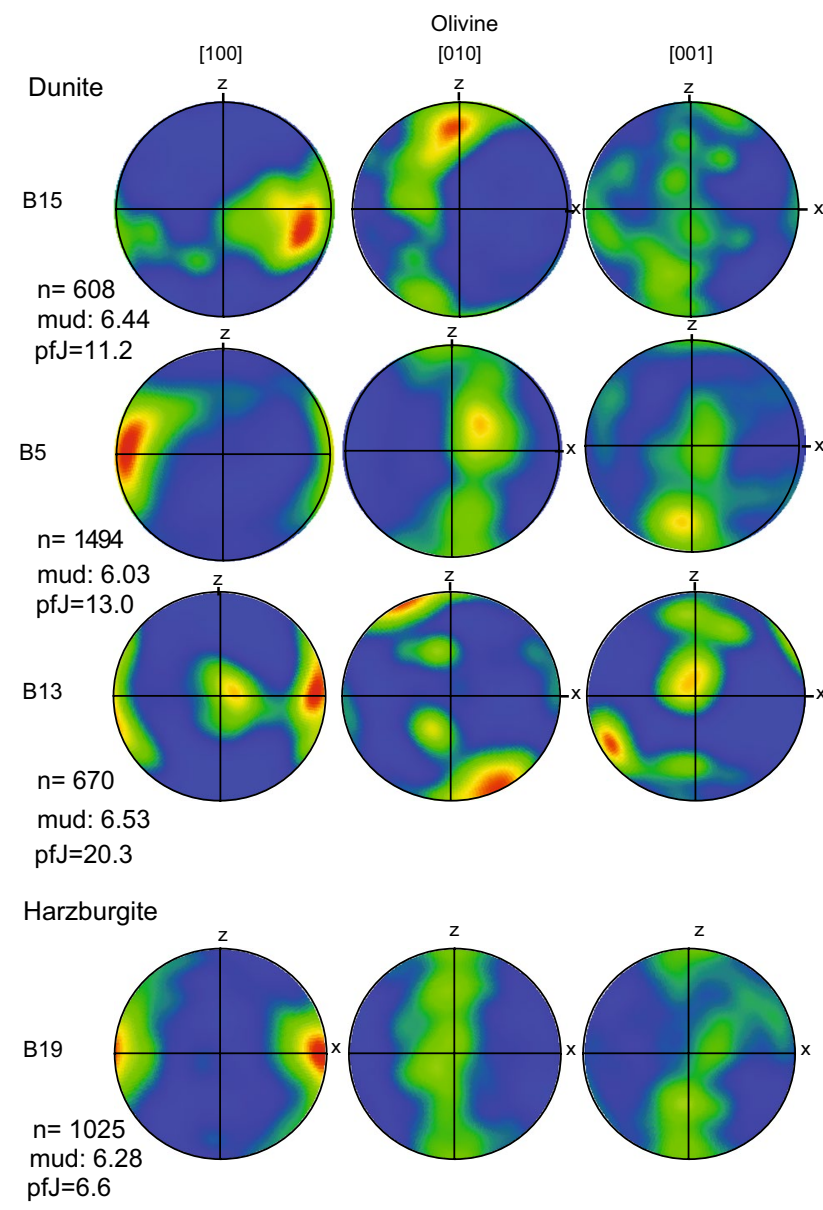

Fig. 7 CPOs of olivine and clinopyroxene in dunite and harzburgite samples. Equal area lower hemisphere stereographic projections in the structural reference frame ( $X$ represents the foliation and $Z$ the normal to the foliation). $n$ is the number of measured grains. Contours at 0.5 multiple of uniform distribution intervals. Mud: contours of multiples of uniform density

20.0, while it is 6.6 and 5.3 in the harzburgite and wehrlite, respectively. In dunites $\mathrm{B} 15$ and $\mathrm{B} 13<010>$ axes are perpendicular to the foliation plane and at low angle to $Z$ $\left(<25^{\circ}\right)$, while in other dunites (B5, B8 and K3) $<010>$ axes are included in the foliation plane (Figs. 7, A1). In dunite B13, olivine $<100>$ axes form two point concentrations where the stronger is sub-parallel to $X$ and the second is sub-parallel to $Y$ (Fig. 7). The second point concentration corresponds to olivine grains distributed in the lower left corner of the thin section (purple grains on Fig. 10), which seem to be smaller than the grains with $<100>$ axes parallel to $X$. For these grains, $<010>$ axes are sub-parallel to $Z$ and $<001>$ axes are at a low angle to $X\left(\sim 25^{\circ}\right)$, an orientation only observed in this small olivine population. Clinopyroxene population in the dunite (samples B15 and B5) is small, but the grains analysed have their $<001>$ axes at a low angle to olivine $<100>$ axes, both sub-parallel to the lineation $(X)$ (Fig. A1).

Olivine CPO in the harzburgite (sample B19) describes a strong concentration on $\langle 100\rangle$ axes parallel to $X$, and girdle distribution of both $<010\rangle$ and $<001>$ normal to the lineation (Fig. 7). Orthopyroxene in the harzburgite shows a strong concentration of $\langle 100\rangle$ axes at a low angle to $Z$ $\left(\sim 20^{\circ}\right)$ and a weak concentration of $<001>$ axes sub-parallel to $X$, at a low angle to olivine $<100>$ axes (Fig. A2).

Wehrlite (sample B14) olivine CPO is characterised by a weak concentration of $\langle 100\rangle$ axes at a low angle to $X$ $\left(\sim 25^{\circ}\right)$ and a strong concentration of $\langle 010\rangle$ axes perpendicular to the foliation plane and sub-parallel to $Z$ (Fig. 8). Clinopyroxene CPO in the wehrlite shows a strong concentration of $<010\rangle$ axes sub-parallel to $Z$ and a weak point concentration on $<001>$ sub-parallel to $Z$ (Fig. 8).

\section{Ol-clinopyroxenite}

The olivine CPO in ol-clinopyroxenite show similar orientation to olivine in peridotites with $<100>$ axes parallel to the lineation $(X)$ and $<010>$ perpendicular to the foliation plane (Fig. 8). In sample B23, clinopyroxene CPO describes $<001>$ axes parallel to the lineation $(X)$ and to olivine $<100>$ axes, while in sample K4 clinopyroxene show dispersed orientation and several point concentrations (Fig. 8). In both samples, the orthopyroxene population is small $(n<89)$ and axes do not show preferred orientation (Fig. A2).

\section{Orthopyroxenite, gabbroic vein and ol-websterite}

The orthopyroxenite vein (within sample K3) has a small population of clinopyroxene where $\langle 001\rangle_{\mathrm{cpx}}$ axes are parallel to $\langle 100\rangle_{{ }_{\mathrm{ol}}}$ axes within the dunite (Figs. 7, A2). Orthopyroxenes from the orthopyroxenite vein have their $<001\rangle$ axes parallel to $\langle 100\rangle_{\text {ol }}$ axes and $\langle 001\rangle_{\text {cpx }}$ axes.

In the gabbroic vein, clinopyroxene CPO shows a scattered distribution, but with some coincidence with the clinopyroxenes from the host wehrlite (Fig. A2), and orthopyroxene does not show preferred orientations.

The olivine fabrics in ol-websterite (sample B9) for parts A and B (Fig. 4j) are similar and describe a strong point concentration on the $\langle 010\rangle$ axes within the foliation plane (parallel to $Y$ ) (Fig. 8). $<100>$ and $<001>$ axes show a weak point concentration sub-parallel or at low angle to the lineation $(X)$ (Fig. 8). Clinopyroxene shows weak $\mathrm{CPO}$, but $<001>$ axes in part A are sub-parallel to the lineation $X$ and to $\langle 100\rangle_{\text {ol }}$ axes, while in part $\mathrm{B}$, clinopyroxenes $<001>$ axes are at $45^{\circ}$ to the lineation (Fig. 8). As observed for the clinopyroxenes, orthopyroxenes in part A have their $<001>$ axes parallel to $\langle 100\rangle_{\mathrm{o}}$, while in part B they are more dispersed (Fig. A2). 


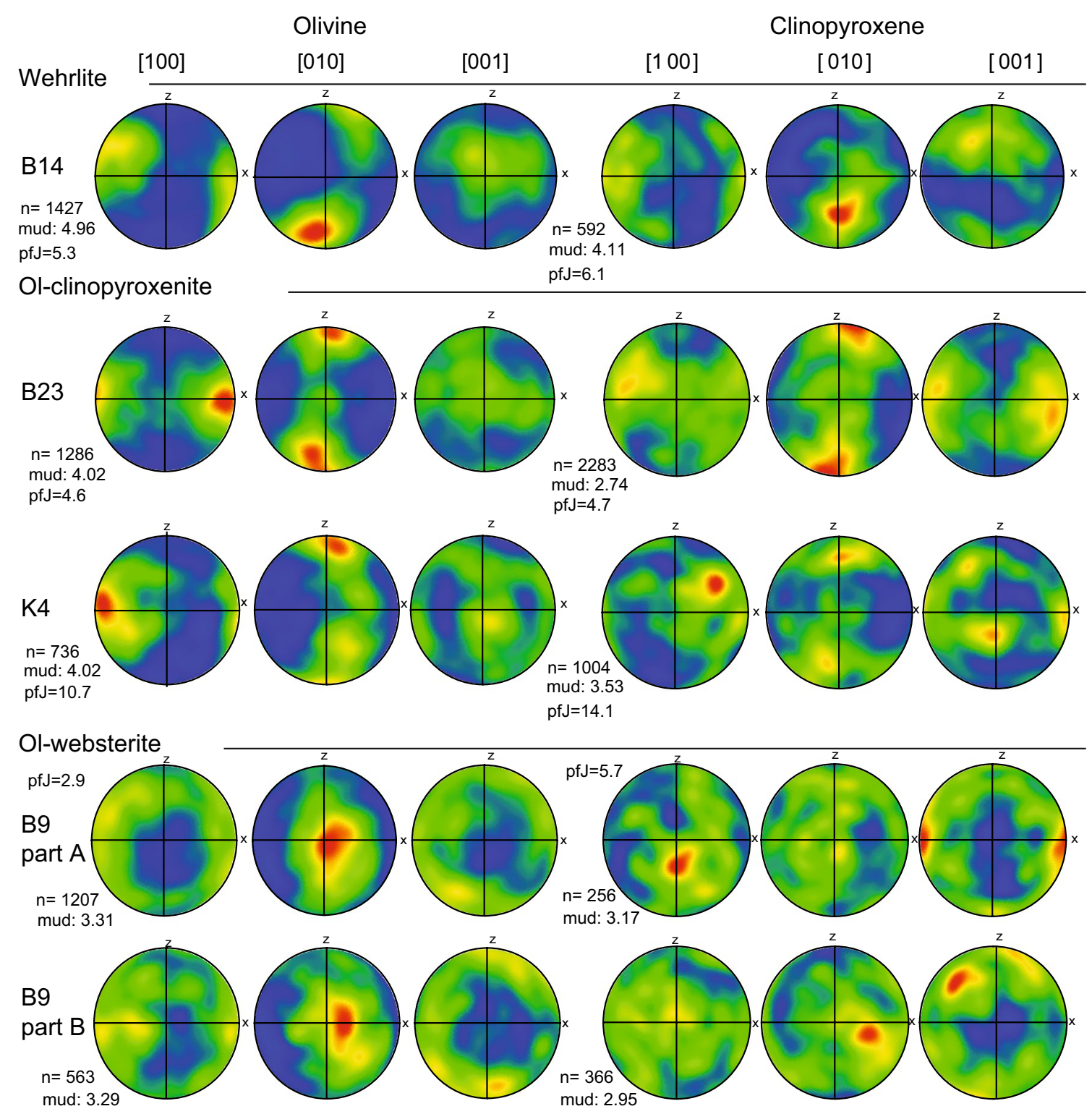

Fig. 8 Olivine and clinopyroxene CPOs in peridotites and pyroxenites. Equal area lower hemisphere stereographic projections in the structural reference frame ( $X$ represents the lineation and $Z$ the nor-

\section{Discussion}

\section{Origin of depleted Marum peridotite}

In the mantle the origin of dunite is recognised to be the result of either fractionation of olivine from a mafic melt forming cumulative dunite; residual dunite formed by intensive partial melting of peridotite (Arai 1994a, b; Le Roux et al. 2014; Tamura and Arai 2006); or peridotitemelt reaction with a melt saturated in olivine and undersaturated in pyroxene (Dick and Bullen 1984; Kelemen et al. 1995; Suhr et al. 2003; Zhou et al. 2005). The olivine mal to the foliation). $n$ is the number of measured grains. Contours at 0.5 multiple of uniform distribution intervals. Mud: contours of multiples of uniform density

$\mathrm{Mg \#}$ and $\mathrm{Cr} \#$ in spinel are good indicators of the degree of partial melting for the mantle derived spinel peridotite and can be used to discriminate the tectonic setting of peridotite (Arai 1994a; Dick and Bullen 1984; Tamura and Arai 2006). Spinel $\mathrm{Cr} \#$ increases with increasing degrees of melting, which could be related to an increasing amount of water (e.g. Gaetani and Grove 1998). Consequently, midocean ridge (MOR) and fracture zones peridotites are less than 0.6 Cr\#, whereas SSZ peridotites have higher $\mathrm{Cr} \#$ up to 0.8 (Arai 1994a; Choi et al. 2008; Dick and Bullen 1984; Gaetani and Grove 1998; Kaczmarek and Müntener 2008; Kelemen et al. 1995). The high Mg\# in Marum olivine (up 
Dunite B5, olivine

(a) Cumulative orientation map

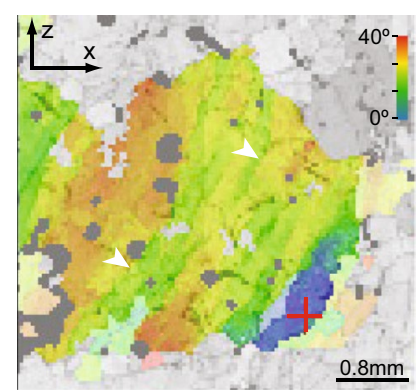

(b) Pole figure of crystallographic axes

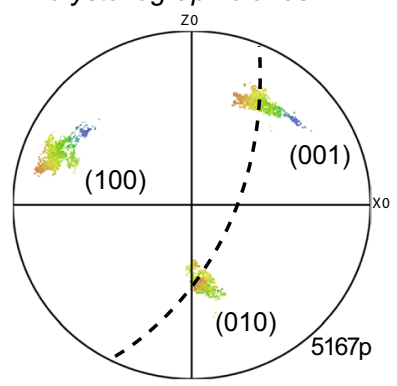

(c) Pole figure of misorientation axes

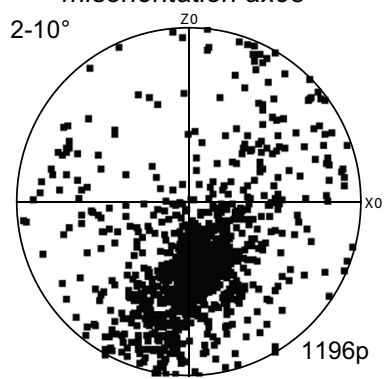

Fig. 9 Orientation map and stereographic projections of crystallographic data for olivine individual grains used to determine the activated slip. a EBSD orientation map coloured for cumulative misorientation (in degrees) relative to reference orientation indicated by a red cross. Each pixel in image represents an orientation analysis derived from a single diffraction pattern. The white arrows show the LAB. b Pole figures of major crystallographic planes for every

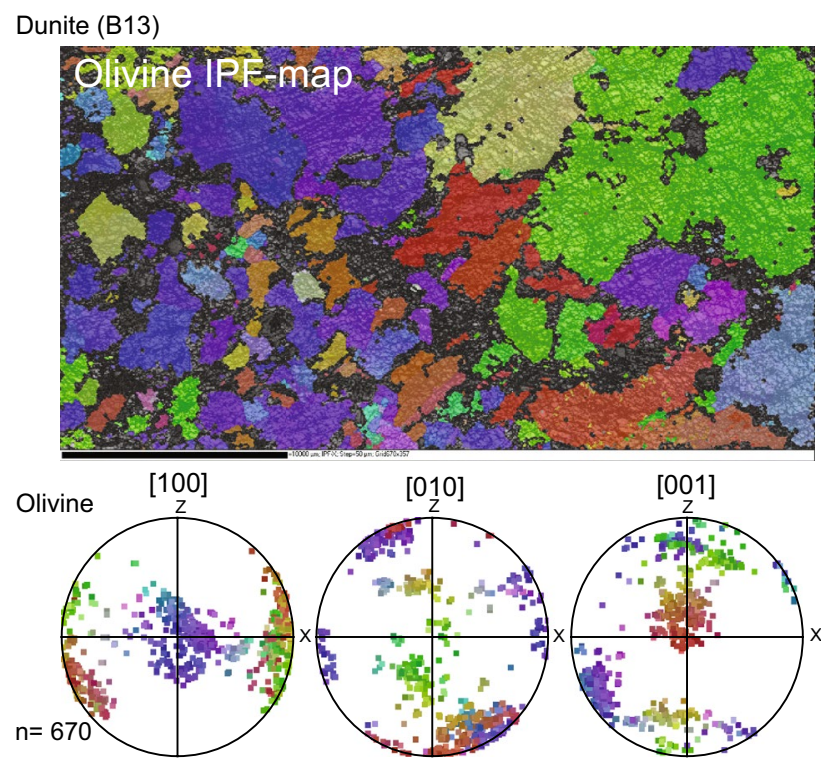

Fig. 10 Olivine inverse pole map and associated poles figures (IPF) of dunite B13. Equal area lower hemisphere stereographic projections in the structural reference frame ( $X$ represents the lineation and $Z$ the normal to the foliation). $n$ is the number of measured grains

to 0.93), as well as the high $\mathrm{Cr} \#$ in spinel (up to 0.83) in dunite and harzburgite denote an extreme depletion of the peridotite as a product of intensive partial melting. High $\mathrm{Cr} \#$ in Marum spinel seen in the Cr\#-in-spinel versus Mg\#in-olivine panel confirm the depleted character of the mantle and highlight a composition similar to mantle from SSZ within the fore-arc peridotite field (Fig. 11) (Arai 1994a). Moreover, clinopyroxenes from SSZ are depleted in Dy and $\mathrm{Yb}$ compared to abyssal peridotite (Jean et al. 2010). Marum clinopyroxenes (except for the wehrlite) have very data point indexed on map (a). LAB observed on a are reported with a dashed line. $\mathbf{c}$ Plot of misorientation axes for $\left(2-10^{\circ}\right)$ interval between neighbouring data points in a are on (010) axes. The inferred slip for this olivine grain is (001)[100]. $\mathbf{b}$ and $\mathbf{c}$ are lower hemisphere equal area stereographic projections in the sample coordinate system $(X-Z)$, and the number of analyses for each is shown in lower right as $p$ (points)

low Dy and $\mathrm{Yb}$ contents $(0.15-0.21$ and $0.082-0.12 \mathrm{ppm}$, respectively) plotting in the lower part of the SSZ field (Fig. 7 in Jean et al. 2010), which confirms the strong SSZ affinity of Marum ophiolite.

\section{Depleted pyroxenes in dunite and harzburgite: melting residue or melt percolation?}

The high degree of depletion recorded by Marum dunite suggests a high degree of partial melting ( $20 \%)$, which can result in complete dissolution of clinopyroxene during dry partial melting (Jaques and Green 1980; Kinzler and Grove 1993; Wasylenki et al. 2003). However, in SSZ the dry melting model cannot be applied and hydrous melting is more appropriate. In that case the proportion of enstatite entering the melt is enhanced relative to clinopyroxene, and the proportion of olivine decreases in response to the incongruent melting of enstatite (e.g. Gaetani and Grove 1998). During such melting, residual clinopyroxene can persist to a higher degree melt fraction (up to $30 \%$ ) and enstatite is depleted more rapidly (Bizimis et al. 2000). Hydrous melting proportions result in residual harzburgite modes with $\sim 82 \%$ modal olivine and $\sim 16 \%$ modal enstatite at clinopyroxene-out (Bizimis et al. 2000; Choi et al. 2008; Gaetani and Grove 1998) proportions observed in Marum harzburgite (Table 1). Moreover, the high spinel $\mathrm{Cr} \#(>0.55)$ that exceeds that of abyssal peridotite might reflect melting of the mantle beyond clinopyroxene-out (Dick and Bullen 1984). Therefore, the orthopyroxene in dunite, harzburgite and centimetric orthopyroxenite veins in the Marum peridotite must be mostly residual after melt extraction and probably has re-equilibrated with melt, while clinopyroxene was probably completely consumed. 

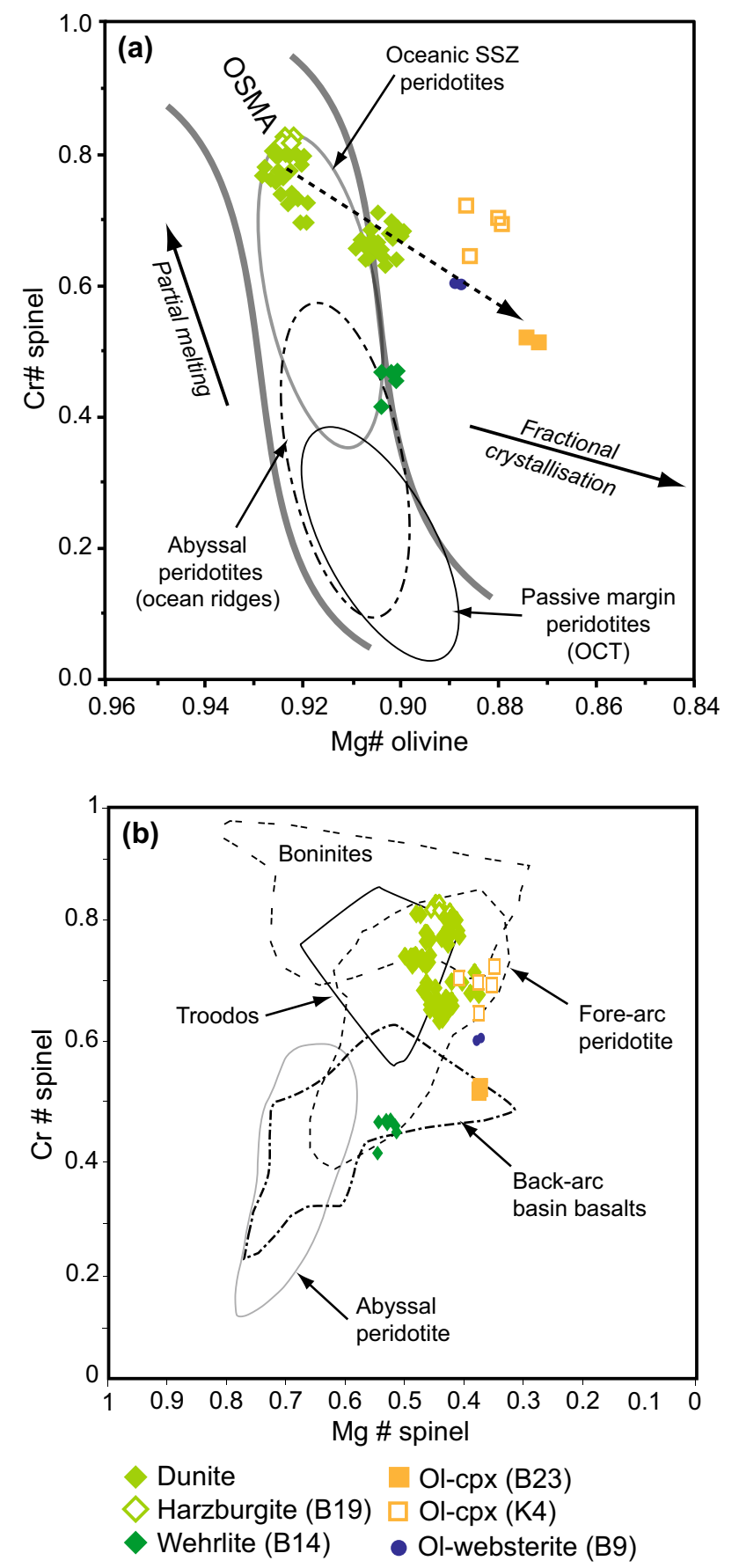

Fig. 11 a Plot of spinel Cr\# versus olivine Mg\# for the Marum peridotite. Olivine-spinel mantle array-OSMA (Arai 1994a). Abyssal peridotite field (mid-ocean ridges) are from Dick and Bullen (1984), passive margins field and supra-subduction zone (SSZ) peridotites are from Pearce et al. (2000). b Discrimination diagrams with Cr\# versus Mg\# of spinel after Kepezhinskas et al. (1993), with spinels from abyssal peridotite (Arai 1994a; Dick and Bullen 1984), fore-arc basin (Bloomer and Fisher 1987; Bloomer and Hawkins 1983; Ishii et al. 1992; Parkinson and Pearce 1998), back-arc basin (Dick and Bullen 1984), boninites (Bloomer and Hawkins 1987; Bonatti and Michael 1989; Cameron 1985; Sobolev and Danyushevsky 1994; Umino 1986; van der Laan et al. 1992), and high Ca-boninites (Troodos) (Cameron 1985). Dashed arrow represents the bonititic trend
The residual hypothesis for Marum orthopyroxenes is supported by the diffuse contact between the orthopyroxene vein and the dunite (Fig. 3), large orthopyroxene grains with exsolution lamellae in harzburgite (Fig. 4c) and their depleted major elements composition (Fig. 5c). Marum dunite and harzburgite orthopyroxenes are more depleted than pyroxenes from dunite or harzburgite from other SSZs, which have been interpreted as residual with partial re-equilibration with melt or precipitated from percolated melt (Choi et al. 2008; Jean et al. 2010; Le Roux et al. 2014; Monnier 1996; Song et al. 2009; Tamura and Arai 2006). Therefore, orthopyroxene from the centimetric vein showing a more HREE-enriched composition than harzburgite indicates, as observed in other ophiolites, a partial reequilibration with melt (Fig. 6b, Jean et al. 2010; Le Roux et al. 2014 and references therein).

\section{Nature of melt percolation in the mantle wedge}

The low proportion of clinopyroxene (1-2\%) observed in highly depleted dunite and harzburgite showing interstitial shape (Fig. 4b) is interpreted to be the product of the precipitation of a small proportion of melt (named percolation 1:P1). It has been showed that melt extraction by percolating through the peridotite during melting is not perfectly efficient, and a small proportion of melt is trapped within the peridotite (e.g. Faul 1997; Sundberg et al. 2010).

The olivine Mg\# decreasing from dunite (0.92) to ol-clinopyroxenite and ol-websterite $(0.87-0.89)$, plus pyroxene-rich areas, pyroxenitic dykes, or gabbroic dykes support a fertilisation hypothesis of the Marum peridotite by a focused melt percolation process. Major element compositions of minerals from ol-clinopyroxenite and ol-websterite show a general enrichment relative to compositions observed in dunite and harzburgite (Fig. 5). Moreover, orthopyroxene from the ol-clinopyroxenite and ol-websterite is enriched in HREE relative to that in the harzburgite (Fig. 6b), indicating precipitation from percolating melt. Dunite spinels fall into two groups following a trend towards ol-clinopyroxenite and ol-websterite in the Cr\#-in-spinel versus Mg\#-in-olivine (Fig. 11a). The position of spinels from ol-clinopyroxenite and ol-websterite, outside the SSZ and olivine-spinel mantle array (OSMA) fields (Arai 1994a) suggests a possible crystal segregation from a magma without affinities to MORB. The high Cr\# character of Marum spinel denotes a linkage to boninite and overlaps spinel compositions from boninite (Bloomer and Hawkins 1987; Bonatti and Michael 1989; Cameron 1985; Sobolev and Danyushevsky 1994; Umino 1986; van der Laan et al. 1992), Troodos ophiolite (Ca-rich boninite) (Cameron 1985) and fore-arc peridotite (Bloomer and Fisher 1987; Bloomer and Hawkins 1983; Ishii et al. 1992; Parkinson and Pearce 1998) (Fig. 11b). 
The nature of the equilibrium melt with Marum peridotite was calculated from trace element concentrations of clinopyroxene from ol-clinopyroxene and ol-websterite using clinopyroxene/melt (boninite) distribution coefficients by Sobolev et al. (1996). The calculated melts are similar not only in HREE concentrations and flat HREE to MREE pattern but also in LREE enrichment, compared to Bonin Islands (Japan) and Cape Vogel (PNG) boninites (Hickey and Frey 1982; König et al. 2010) (Fig. 12). It has been recognised that the first magma formed in response to subduction initiation and fore-arc extension is boninitic in composition, derived by partial melting of hydrated oceanic lithosphere in the mantle wedge (Bloomer et al. 1995; Pearce et al. 1984; Stern and Bloomer 1992). The chemical trend from dunite and harzburgite to ol-clinopyroxenite and ol-websterite indicates the chemical evolution of a melt with boninitic affinities, accompanied by a change in the percolation mechanisms from a diffuse (dunite, harzburgite) to a more focused flow (pyroxenite dykes). This event is named P2 (percolation 2). The latter is observed with ol-websterite such as intrusive dyke-like morphology and sharp boundaries with the host dunite, suggesting that the dykes are probably the product of crystal fractionation during melt migration in the upper mantle (Fig. 13a, b). In that case ol-clinopyroxenite (P2a), which has more diffused contact with the host dunite, could be formed prior to ol-websterite (P2b). This relative short timing is also supported by the slight enrichment in trace and major elements of clinopyroxene and orthopyroxene from ol-clinopyroxenite to ol-websterite (Figs. 5, 6). The change in percolation mechanisms from diffuse (P1) to a more focused flow (P2) could be induced by an increasing proportion of melt in the system accompanied by cooling due to the exhumation of the mantle during proto fore-arc spreading. The diffuse contacts of ol-clinopyroxenite suggest crystallisation of minerals in a melt-filled dyke related to a large melt proportion ( $\mathrm{P} 2 \mathrm{a})$, and a decrease in temperature permits rock fracturing and dykes crystallisation with sharp contacts to the host peridotite $(\mathrm{P} 2 \mathrm{~b})$.

Another enrichment of the peridotite is identified as the precipitation of clinopyroxene with high $\mathrm{Al}_{2} \mathrm{O}_{3}$ content (1.66-3.32 wt\%) associated with plagioclase forming locally wehrlite and centimetric gabbroic veins (Figs. 4e, f, $5 \mathrm{~b}, 13 \mathrm{c})$. In the wehrlite, olivine has the same composition as olivine in the dunite, but clinopyroxene and orthopyroxene register the more enriched compositions observed in the studied Marum peridotites (Figs. 5, 6). Wehrlite clinopyroxene REE composition plots in the abyssal peridotite field (Johnson and Dick 1992; Johnson et al. 1990) (Fig. 6a), and spinel has a composition plotting close to the abyssal peridotites and partially overlapping the back-arc basin basalts field (Dick and Bullen 1984) (Fig. 12a). Plagioclase is similar in composition to plagioclase originating

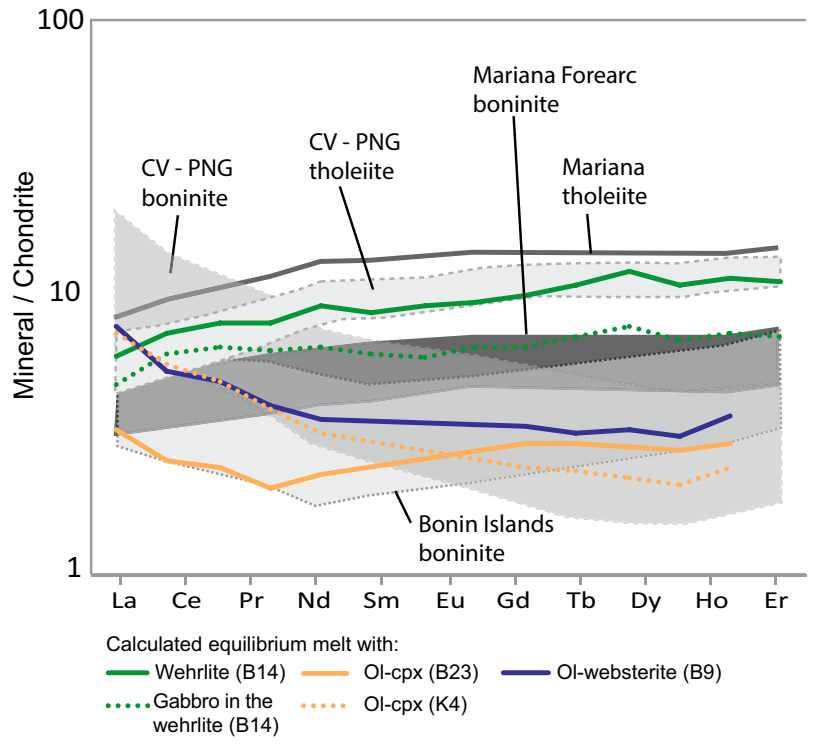

Fig. 12 Calculated compositions of theoretical melts in equilibrium with clinopyroxene in the Marum ophiolite. We used the partition coefficients between clinopyroxene and bonititic melt of Sobolev et al. (1996) for ol-clinopyroxenite and ol-websterite and the partition coefficients between clinopyroxene and basaltic melt of Hart and Dunn (1993) for the wehrlite. Boninite and tholeiite field compositions from Cape Vogel, Papua New Guinea (CV-PNG) (Hickey and Frey 1982; König et al. 2010) are reported as well as boninite from Bonin Islands (Japan) and Mariana fore-arc (DSPS site 458) plus associated tholeiite from Mariana site 458 (Hickey and Frey 1982). Trace elements are normalised to chondrite (McDonough and Sun 1995)

from melt percolation (Kaczmarek and Müntener 2008, with similar trace element and positive Eu anomaly) and in the Cr\#-in-spinel versus Mg\#-in-olivine diagram the depleted group of dunite shows a slight trend towards the wehrlite. All together these results suggest another type of fertilisation with tholeiite affinities (Fig. 11a), an event named P3 (percolation 3). Indeed, calculated equilibrium melt with clinopyroxene from wehrlite using clinopyroxene/melt (basalt) distribution coefficients by Hart and Dunn (1993) shows a trend similar to tholeiite (Fig. 12) (Hickey and Frey 1982). Pearce et al. (1984) suggest that during subduction processes, the magma composition changes from boninite to island arc tholeiite and significant volumes of boninite lavas have been shown to be overlain by tholeiitic arc lavas in Cyprus-Troodos (Cameron 1985) and PNG-Cape Vogel (Walker and McDougall 1982). Moreover, in Cape Vogel, tholeiitic basalts and boninite lavas have similar $\mathrm{K}-\mathrm{Ar}$ and ${ }^{40} \mathrm{Ar} /{ }^{39} \mathrm{Ar}$ ages (58.8 and 58.9 for boninite and tholeiite lavas, respectively) indicating contemporaneous volcanism (Walker and McDougall 1982). This suite has been interpreted as evidence for continuous magma extraction from a progressively depleted and hydrated mantle wedge (Crawford et al. 1989). This indicates that 
(a) P1 (boninite)

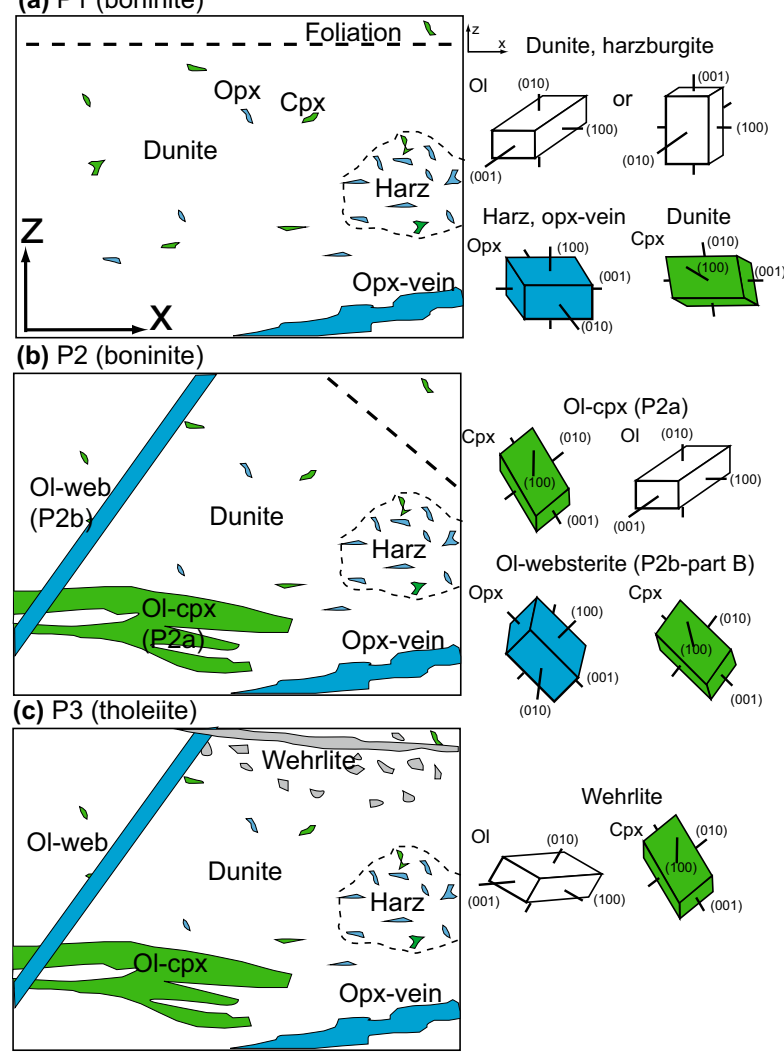

Fig. 13 Schematically representations of boninitic and tholeiitic melt percolation (59-58 Ma, Walker and McDougall 1982) in the Marum peridotite and associated orientation of minerals. a Host main rock is dunite with some residual harzburgite areas, and centimetric orthopyroxenite vein with diffuse contact to the dunite. Isolated orthopyroxene grains in the host dunite are interpreted as residual, but clinopyroxene is precipitated from melt (P1). Olivine $<100>$ axes and cpx and opx <001> axes are parallel to the foliation. b Ol-clinopyroxenite rich areas $(\mathrm{P} 2 \mathrm{a})$ and ol-websterite $(\mathrm{P} 2 \mathrm{~b})$ crystallisation across the dunite. In part B of the ol-websterite, opx and cpx have their $<001>$ axes at $45^{\circ}$ to the principal foliation. c Crystallisation of wehrlite showing tholeiitic affinities (P3). Olivine $<100>$ and $\operatorname{cpx}<001>$ axes are oblique to the initial foliation $\left(\sim 60^{\circ}\right)$. $\mathrm{P}$ percolation, $\mathrm{Ol}$ olivine, $O p x$ orthopyroxene, $C p x$ clinopyroxene, Harz harzburgite. The dashed line represents the foliation. See text for discussion

the formation of wehrlite (P3) was contemporaneous with or later than the formation of ol-clinopyroxenite (P2a) and ol-websterite (P2b) during the boninitic percolation event though there have been no field observations to confirm this (Fig. 13c). Finally, large gabbroic dykes (anorthosite and minor olivine gabbro) cross-cut the previous structures and probably are the result of a larger amount of melt within the mantle sequence focusing into dykes (Fig. 3h, i).

All temperatures estimates are in the same range from depleted dunite to ol-websterite or wehrlite with an average of $948 \pm 66{ }^{\circ} \mathrm{C}$ using $\mathrm{Opx}_{\mathrm{BK} 90}$, a temperature of $915 \pm 54{ }^{\circ} \mathrm{C}$ in a dunite $\left(\mathrm{Ol}-\mathrm{Sp}_{\mathrm{Ba} 91}\right)$ and lower for $2 \operatorname{Prx}_{\mathrm{BK} 90} 781 \pm 20^{\circ} \mathrm{C}$. These temperatures are similar to temperatures recorded for most other supra-subduction peridotites varying between 700 and $975{ }^{\circ} \mathrm{C}$ (Kim and Jung 2014; Michibayashi et al. 2007; Mizukami et al. 2004; Skemer et al. 2006; Wang et al. 2013; Webber et al. 2008). These temperatures are relatively low for high degree of melting and melt percolation processes. They suggest a fast diffusion of major elements after melting and melt percolation processes, and they record post-melting thermal equilibration at subsolidus conditions.

\section{Inferred slip systems in dunite and harzburgite}

In dunite and harzburgite (depleted samples) olivine CPOs $<100>$ axes describe a strong point concentration parallel to the lineation and $<001>$ or $<010>$ axes perpendicular to the foliation plane, LAB (Figs. 7, 9, A1), suggesting that olivine was deformed by dominant (001)[100] E-type slip system in most samples (Jung et al. 2006; Karato et al. 2008; Katayama et al. 2004), and by (010)[100] A-type slip system (Jung et al. 2006; Nicolas and Poirier 1976) in dunites B15 and B13 (Fig. A1). E-type fabrics are widespread in the asthenosphere, have been also identified in the lithosphere (Kaczmarek and Reddy 2013; Karato et al. 2008; Palasse et al. 2012; Sawaguchi 2004) and are developed at relatively low-stress, modest or low water content and high temperatures (Katayama et al. 2004; Palasse et al. 2012). (010)[100] is the more common slip system observed in oceanic and continental lithosphere and is recognised to be favoured at low-stress, high-temperature conditions (Ben Ismail and Mainprice 1998; Nicolas et al. 1971). Moreover, in SSZs, (010)[100] and (001)[100] slip systems have been observed to be the most common activated slip systems (Harigane et al. 2013; Hidas et al. 2007; Kim and Jung 2014; Michibayashi et al. 2009, 2007; Park and Jung 2014; Soustelle et al. 2013; Wang et al. 2013; Webber et al. 2008) after the (100)[001] B-type (Jung et al. 2006) predicted to be activated in the fore-arc mantle wedge (Kneller 2007) and observed in natural peridotite from subduction environments (e.g. Mizukami et al. 2004; Park and Jung 2014; Skemer et al. 2006; Tasaka et al. 2008). In dunite B13 the smaller olivine grains (purple grains on Fig. 10) have their $<001>$ axes at low angle to $X,<010>$ axes perpendicular to the foliation plane and $\langle 100\rangle$ axes within the foliation plane (parallel to $Y$ ), indicating a possible activation of (010)[001] (B-type) slip system. This variation could be related to melt segregation during deformation has observed in experiments (Holtzman et al. 2003). However, B-type is considered to be minor fabric in the Marum ophiolite and will not be further discussed.

The orthopyroxene population in the harzburgite (sample B19) and in the centimetric vein in the dunite (sample K3) have their $<001>$ axes parallel to lineation $(X)$ and $<100>$ axes or $<010>$ axes perpendicular to the foliation 
plane, respectively (Fig. A2). The deformation of orthopyroxene was dominated by the activation of (100)[001] and (010)[001] slip systems, which are common for pyroxenes where deformation is presumed to be at high temperature (e.g. Dornbush et al. 1994; Nicolas and Poirier 1976). The maximum concentration of olivine $\langle 100\rangle_{\mathrm{ol}}$ axes and of $<001\rangle_{\text {opx }}$ axes when parallel to the lineation are the dominant glide directions for these minerals at high-temperature, low-pressure conditions (Nicolas and Poirier 1976; Tommasi et al. 2000). $\langle 100\rangle_{\text {ol }}$ and $\langle 001\rangle_{\text {opx }}$ axes are usually sub-parallel in dunite, harzburgite and the centimetric orthopyroxenite vein and so indicate syn-kinematic deformation or epitaxial growth (Baptiste et al. 2012; Kaczmarek and Tommasi 2011) (Figs. A2, 13a). The centimetric orthopyroxene vein in the dunite (Fig. 4i), which is thought to be residual after peridotite melting based on geochemistry and petrology, and the olivine constituting dunite and harzburgite probably record the deformation condition of the mantle prior to melt percolation.

\section{Relationships between mineral orientation and melt percolation}

Geochemical data indicate a complex sequence of events with fertilisation of a highly depleted mantle by boninitic (P1-P2) and tholeiitic (P3) melts, and a progression from diffuse percolation of a small melt fraction to a focused percolation of large melt fraction. This scenario is also supported by the behaviour of olivine and pyroxene CPOs.

In the dunite, the small population of clinopyroxene grains derived from diffuse melt percolation (P1), have $\langle 001\rangle_{\mathrm{cpx}}$ axes sub-parallel to lineation and a CPO pattern resembling that of olivine $\left(\langle 100\rangle_{\mathrm{ol}}\right.$ axes parallel to lineation, Figs. 13a, A1). This indicates syn-kinematic deformation or epitaxial growth of olivine and clinopyroxene (Baptiste et al. 2012; Kaczmarek and Tommasi 2011) as already observed in the harzburgite, and orthopyroxenite vein in the dunite $(<001\rangle_{\text {opx }}$ axes sub-parallel to $\langle 100\rangle_{\text {ol }}$, Figs. 13a, A2).

The crystallisation of ol-clinopyroxenites B23 and K4 and ol-websterite B9 have been interpreted to be derived from melt percolation with boninitic affinities (P2), and the wehrlite B14 has derived from melt with tholeiitic affinities (P3). In ol-clinopyroxenites, olivine which is not the dominant phase (up to $22 \%$, Table 1) shows $\langle 100\rangle_{\mathrm{ol}}$ axes describing a strong concentration parallel to the lineation and $\langle 010\rangle$ axes perpendicular to the foliation plane (Figs. 8, A2, 13b), suggesting the dominant activation of (010)[100] slip system. In the wehrlite, olivine CPOs pattern are similar to those in ol-clinopyroxenites with the possible activation of an (010)[100] slip system, but with an obliquity to ol-clinopyroxenite patterns $(<100\rangle_{\mathrm{ol}}$ axes at $30^{\circ}$ to the lineation, Fig. 13c). Olivine CPOs from ol-websterite B9 show $<100>$ axes describing a weak concentration parallel to the lineation and $<010\rangle$ axes a strong concentration within the foliation plane indicating the possible activation of a (001)[100] slip system (Fig. 8) (e.g. Jung et al. 2006; Karato et al. 2008; Katayama et al. 2004). (010)[100] and (001)[100] slips are the same slips as those observed in dunite and harzburgite from the Marum ophiolite. However, olivine CPOs are weaker than in dunites and harzburgite (mud up to 4.96 against $>6.72$ in dunite and harzburgite) and have a $J$-index between 3 and 10, while it is higher than 11.2 in the dunites (Figs. 7, 8), suggesting a melt participation in the system. It has been shown that when plastic deformation occurs after and/or simultaneously with partial melting, the newly crystallised grains are expected to weaken any strong pre-existing mineral fabrics (e.g. Morales and Tommasi 2011; Tommasi et al. 2004), and melt can favour melt-enhanced diffusional creep and lead to a decrease in mineral fabric intensity (e.g. Hirth and Kohlstedt 1995; Holtzman and Kohlstedt 2007).

In ol-clinopyroxenite B23 (P2a), clinopyroxene exhibits $<001>$ axes at a low angle to the lineation $\left(\sim 15^{\circ}\right)$, and $<010>$ axes perpendicular to the foliation plane indicating the activation of (010)[001] slip system (Fig. A2). Clinopyroxene CPOs of ol-clinopyroxene $\mathrm{K} 4$ is weak but shows the activation of the same slip system with a small population of $<001>$ axes parallel to the lineation and $<010>$ axes perpendicular to the foliation plane. This slip system is common for clinopyroxene deformed at high temperature (e.g. Bascou et al. 2001; Van Roermund and Boland 1981). In ol-clinopyroxenite $\langle 100\rangle_{\text {ol }}$ axes parallel to $\langle 001\rangle_{\mathrm{cpx}}$ axes suggest a possible syn-kinematic deformation or epitaxial growth (Baptiste et al. 2012; Kaczmarek and Tommasi 2011). The same observation can be made within the ol-websterite (P2b) part A, where $\langle 001\rangle_{\mathrm{cpx}}$ and $\langle 001\rangle_{\mathrm{opx}}$ axes are parallel to $\langle 100\rangle_{\mathrm{ol}}$ axes, while they are discordant in part B $\left(45^{\circ}\right.$ to the lineation) where the proportion of clinopyroxene is higher (Figs. 4j, 8, 13b). The concordance of olivine and pyroxene crystallographic axes in part A suggests epitaxial growth, while where the melt proportion has increased pyroxenes crystallised under their own constraints and crystallographic axes became discordant. This is also illustrated with the distribution of $\langle 001\rangle_{\mathrm{cpx}}$ axes in ol-clinopyroxenite K4 (P2a) showing several point concentrations and where one population has $\langle 001\rangle_{\mathrm{cpx}}$ axes clearly discordant to $\langle 100\rangle_{\mathrm{ol}}$ axes, at $60^{\circ}$ to the lineation (Figs. 8, 13b). This population also occurred in the wehrlite $\left(60^{\circ}\right)$ (Figs. $8,13 \mathrm{c}$ ). The high angle between $\langle 001\rangle_{\mathrm{cpx}}$ axes and $\langle 100\rangle_{\text {ol }}$ axes indicates a reorientation of the constraints of almost $60^{\circ}$ from the "primary" mantle (conditions prior to melting or during melting) to the crystallisation of boninitic (P2) and tholeiitic (P3) melts.

Altogether, these observations suggest that the first fraction of melt (P1) crystallised under the same deformation 
constraints as the depleted dunite or by epitaxial growth for a low melt proportion diffused in the peridotite. This has also been observed with P2b within ol-websterite (B9) where the dispersed clinopyroxenes record the same orientation as the primary minerals (part A), but when the proportion of melt increases (part B) newly crystallised pyroxenes record their own orientation, which are at an angle between $45^{\circ}$ and $60^{\circ}$ to the olivine of the dunite. The wehrlite (P3) crystallised in the same constraints as P2 with clinopyroxene $<001>$ axes at $60^{\circ}$ to olivine $<100>$ axes. This similarity between P2 and P3 is not surprising because both boninitic and tholeiitic events are similar in age (Walker and McDougall 1982).

\section{Conclusions and geodynamical implications}

The Marum ophiolite represents a frozen piece of one of the most depleted peridotite among worldwide in a fore-arc position (Figs. 5, 6, 11). The ophiolite records two stages of melt percolations by both boninitic and tholeiitic melts (Fig. 13). Despite local enrichment the Marum mantle rocks remain more depleted than other peridotites such as ophiolites from the Indonesian part of the island (Monnier 1996), or other ophiolite complexes from supra-subduction settings (Choi et al. 2008; Le Roux et al. 2014; Tamura and Arai 2006; Webber et al. 2008).

In a fore-arc position olivine B-type fabrics are predicted to operate (Kneller et al. 2007) but are almost nonexistent in the Marum ophiolite (small population in dunite B13, Fig. 10), while E- and A-type fabrics dominate the deformation in the host dunite and harzburgite (Figs. 7). Absence of olivine B-type has already been observed in other SSZ peridotites (Harigane et al. 2013; Mehl et al. 2003; Soustelle et al. 2013) and could be related to not favourable conditions to initiate [001] slip, or short activity (few Ma) of the Marum ophiolite. The coarse-grained texture and olivine strong crystal fabrics (strong $J$-index) could be formed at near-subsolidus temperature during asthenospheric flow consistent with the foliation and lineation in the dunite. Moreover, activation of A- and E-type slip systems are consistent with high-temperature, lowstress mantle deformation (Nicolas et al. 1971; Ben Ismaïl and Mainprice 1998; Jung et al. 2006) and are probably the result of plastic deformation during the formation of the Marum ophiolite (60-65 Ma, Davies and Jaques 1984; Jaques 1980; Whattam 2009; Whattam et al. 2008), prior to melt percolation in the mantle wedge (Paleocene, $59 \mathrm{Ma}$, Walker and McDougall 1982) and the obduction of the ophiolite (58 Ma, Lus et al. 2004). The orientation of the foliation and olivine [100] slip directions are sub-parallel to subduction zone (Figs. 1, 2, 14a), indicating that mantle flow was parallel to the trench. This is, to our knowledge, the second record for analogue fast polarisation directions

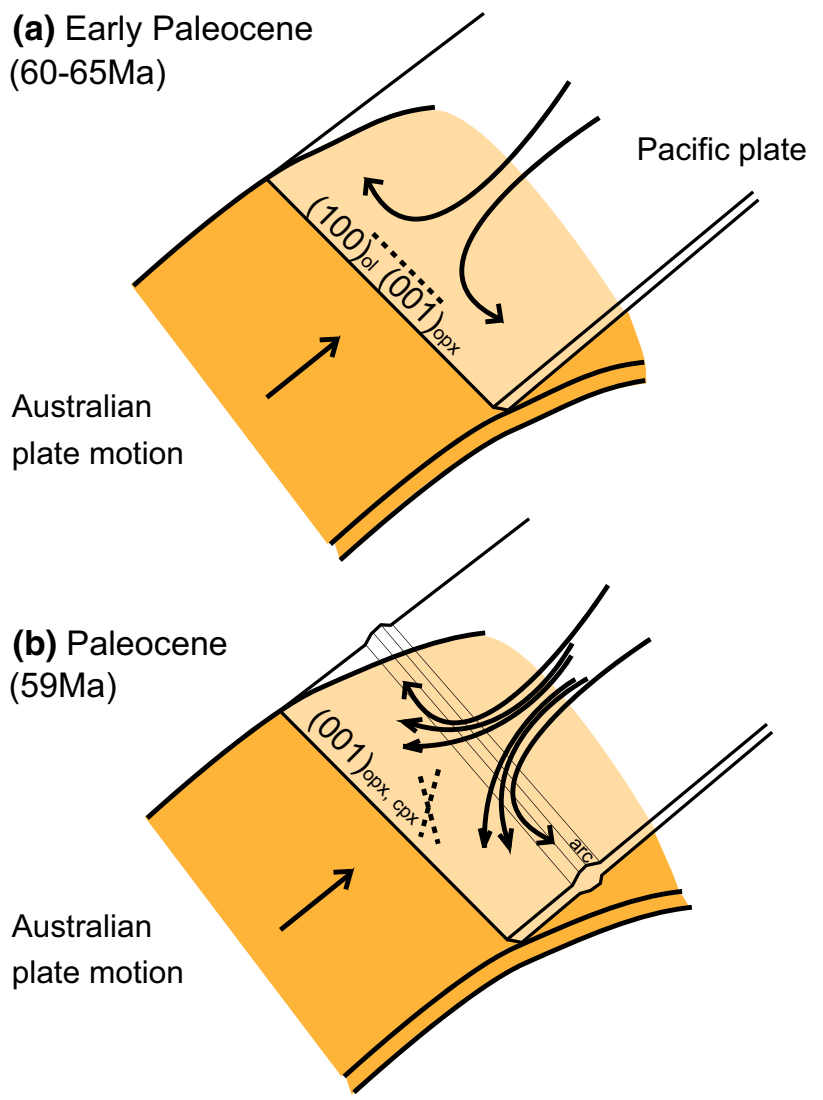

Fig. 14 Sketch of mantle flow during arc formation within the Marum ophiolite. a Ophiolite formation (early Paleocene), with trench parallel mantle flow (foliation is parallel to the trench). b Mantle flow during arc formation, where the newly formed minerals related to melt percolation $\mathrm{P} 2$ and $\mathrm{P} 3$ (boninitic and tholeiitic melts, respectively) recorded an orientation varying from $30^{\circ}$ to $60^{\circ}$ to the primary foliation. Arrows represent variation of lateral mantle flow within the mantle wedge

parallel to the arc axis after Mehl et al. (2003) in Central Alaska, suggesting that the fast polarisation direction parallel to the arc could be caused by anisotropic peridotite and not by olivine [001] slip.

Percolation of boninitic melt is related to young and warm arc in a spreading fore-arc position (Crawford et al. 1989; Kim and Jacobi 2002). The newly formed pyroxenes in the ol-websterite, ol-clinopyroxenite and the wehrlite with pyroxenes $<001>$ axes at $45-60^{\circ}$ to the olivine lineation $\left(<100>_{\mathrm{ol}}\right.$ axes) suggest a change in the constraints during the percolation of boninitic and tholeiitic melts at $59 \mathrm{Ma}$ (Walker and McDougall 1982) (Fig. 14b). Olivine pre-existing CPOs can be modified with progressive strain (Skemer et al. 2011), but have not been overprinted at this stage in the Marum peridotite. Only the newly formed pyroxenes are oriented relative to the applied stress. The change in the orientation has happened between the formation of the ophiolite (60-65 Ma, Davies and Jaques 1984; 
Jaques 1980; Whattam 2009; Whattam et al. 2008) and the melt percolation at $59 \mathrm{Ma}$ (Walker and McDougall 1982) in the young spreading fore-arc. This indicates that olivine pre-existing CPOs need more than $5 \mathrm{Ma}$ to be modified in this context. This change in the orientation can be the result of complex mantle flow within the mantle wedge, producing different flows such as upwelling and/or lateral asthenospheric flow under low stress (Fig. 14b) (Harigane et al. 2013; Mehl et al. 2003). The variation from ol $<100>$ axes parallel to the trench to variation up to $60^{\circ}$ could be an indicator for the development of young fore-arc mantle in a supra-subduction zone.

Acknowledgments Thanks to C. Nevado and D. Delmas for highquality polished thin sections for EBSD measurements and L. Nicod for high-quality thin sections for LA-ICP-MS measurements. And thanks to A. Ulianov for his help with the LA-IPC-MS. The authors thank L. Jaques for providing data from his $\mathrm{PhD}$ and helpful comments on the manuscript. The authors thank the European Union project Geomap, Geological Survey of Papua New Guinea for funding the project "Geological mapping and Mineral Potential Assessment of the PNG highlands". MAK postdoctoral research in Montpellier was funded by the Institut National des Sciences de l'Univers-Centre National de la Recherche Scientifique (INSU-CNRS, France). MAK thanks the Swiss National Science Foundation (SNSF) for support from Ambizione fund NSF-26083906. The EBSD-SEM national facility in Montpellier is supported by the INSU-CNRS and by the Conseil Régional Languedoc-Roussillon, France. Thank you to T.L. Grove editor's comments and two anonymous reviewers giving constructive comments to improve the manuscript.

\section{References}

Adams BL, Wright SI, Kunze K (1993) Orientation imaging: the emergence of a new microscopy. Mettal Trans A24:819-831

Arai S (1994a) Characterization of spinel peridotites by olivine-spinel compositional relationships: review and interpretation. Chem Geol 113:191-204

Arai S (1994b) Compositional variation of olivine chromian spinel in $\mathrm{Mg}$ rich magmas as a guide to their residual spinel peridotites. J Volcanol Geoth Res 59:279-293

Baldwin SL, Fitzgerald PG, Webb LE (2012) Tectonics of the New Guinea Region. Annu Rev Earth Planet Sci 40:495-520

Ballhaus C, Berry RF, Green DH (1991) High pressure experimental calibration of the olivine-orthopyroxene-spinel oxygen geobarometer; implications for the oxidation state of the upper mantle. Contrib Miner Petrol 107(1):27-40

Baptiste V, Tommasi A, Demouchy S (2012) Deformation and hydration of the lithospheric mantle beneath the Kaapvaal craton, South Africa. Lithos 149:31-50

Bascou J, Barruol G, Vauchez A, Mainprice D, Egydio-Silva M (2001) EBSD-measurements lattice-preferred orientations and seismic properties of eclogites. Tectonophysics 342:61-80

Ben Ismail W, Mainprice D (1998) An olivine fabric database: an overview of upper mantle fabrics and seismic anisotropy. Tectonophysics 296:145-157

Bestmann M, Prior DJ (2003) Intragranular dynamic recrystallization in naturally deformed calcite marble: diffusion accommodated grain boundary sliding as a result of subgrain rotation recrystallization. J Struct Geol 25:1597-1613
Bizimis M, Salters VJM, Bonatti E (2000) Trace and REE content of clinopyroxenes from supra-subduction zone peridotites. Implications on melting and enrichment processes in island arcs. Chem Geol 165:65-85

Bloomer SH, Fisher RL (1987) Petrology and geochemistry of igneous rocks from the Tonga Trench-a non-accreting plate boundary. J Geol 95:469-495

Bloomer SH, Hawkins JW (1983) Gabbroic and ultramafic rocks from the Mariana Trench: an island arc ophiolite. In: Hayes DE (ed) The tectonic and geologic evolution of Southeast Asian Seas and Islands, Part 2, vol 27. AGU, Geophysics Monograph, pp 294-317

Bloomer SH, Hawkins JW (1987) Petrology and geochemistry of boninite series volcanic rocks from the Mariana Trench. Contrib Miner Petrol 97:469-495

Bloomer SH, Taylor B, MacLeod CJ, Stern RJ, Fryer P, Hawkins JW, Johnson L (1995) Early arc volcanism and the ophiolite problem; a perspective from drilling in the western Pacific. In: Taylor B, Natland J (eds) Active margins and marginals basins of the Western Pacific, vol 88. American Geophysical Union, Washington, pp 1-30

Bonatti E, Michael PJ (1989) Mantle peridotites from continental rifts to ocean basins to subduction zones. Earth Planet Sci Lett 91:297-311

Boyle AP, Prior DJ, Banham MH, Timms NE (1998) Plastic deformation of metamorphic pyrite: new evidence from electron backscatter diffraction and forescatter orientation-contrast imaging. Mineral Depos 34:71-81

Brey GP, Köhler T (1990) Geothermobarometry in four-phase lherzolites II. New thermobarometers, and practical assessment of existing thermobarometers. J Petrol 31(6):1353-1378

Bunge HJ (1982) Texture analysis in materials sciences. Buttleworth, London

Cameron WE (1985) Petrology and origin of primitive lavas from the Troodos ophiolite, Cyprus. Contrib Miner Petrol 89:239-255

Choi SH, Shervais JW, Mukasa SB (2008) Supra-subduction and abyssal mantle peridotites of the Coast Range ophiolite, California. Contrib Miner Petrol 156:551-576

Crawford AJ, Falloon TJ, Green DH (1989) Classification, petrogenesis and tectonic setting of Boninites. In: Crawford AJ (ed) Boninites. Unwin Hyman, Boston, pp 1-49

Daly MC, Cooper MA, Wilson I, Smith DG, Hooper BGD (1991) Cenozoic plate tectonics and basin evolution in Indonesia. Mar Pet Geol 8:2-21

Davies HL (1971) Peridotite-gabbro-basalt complex in eastern Papua: an overthrust plate of oceanic mantle and crust. Bur Miner Resour Aust Bull 128:48

Davies HL (2012) The geology of New Guinea-the cordilleran margin of the Australian continent. Episodes 35(1):87-102

Davies HL, Jaques AL (1984) Emplacement of ophiolite in Papua New Guinea. Special publication. Geological Society of London, London

Davies HL, Smith IE (1971) Geology of eastern Papua. Bull Geol Soc Am 82:8299-8312

Dick HJB (1989) Abyssal peridotites, very slow spreading ridges and ocean ridge magmatism. In: Saunders AD, Norry M (eds) Magmatism in the ocean basins, vol 42. Geological Society Special Publication of London, pp 71-105

Dick HJB, Bullen T (1984) Chromian spinel as a petrogenetic indicator in abyssal and alpine-type peridotites and spatially associated lavas. Contrib Miner Petrol 86(1):54-64

Dornbush HJ, Weber K, Skrotzki W (1994) Development of microstructure and texture high-temperature mylonites from the Ivrea Zone. In: Bunge HJ, Siegesmund S, Skrotzki W, Weber K (eds) Textures of geological meterials, vol DGM informationsges, Oberursel, pp 187-201 
Faul UH (1997) Permeability of partially molten upper mantle rocks from experiments and percolation theory. J Geophys Res 102:10299-10311

Franz L, Becker K-P, Kramer W, Herzig PM (2002) Metasomatic mantle xenoliths from Bismarck microplate (Papua New Guinea) - thermal evolution, geochemistry and extent of slabinduced metasomatism. J Petrol 43(2):315-343

Gaetani GA, Grove TL (1998) The influence of water on melting of mantle peridotite. Contrib Miner Petrol 131:323-346

Grégoire M, McInnes BIA, O'Reilly SY (2001) Hydrous metasomatism of oceanic sub-arc mantle, Lihir, Papua New Guinea, Part 2. Trace element characteristics of slab-derived fluids. Lithos 59:91-108

Harigane Y, Michibayashi K, Morishita T, Tani K, Dick HJB, Ishizuka O (2013) The earliest mantle fabrics formed during subduction zone infancy. Earth Planet Sci Lett 377-378:106-113

Hart SR, Dunn T (1993) Experimental cpx/melt partitioning of 24 trace elements. Contrib Miner Petrol 113(1):1-8

Hickey RL, Frey FA (1982) Geochemical characteristics of boninite series volcanics: implications for their source. Geochim Cosmochim Acta 46:2099-2115

Hidas K, Falus G, Szabó C, Szabó PJ, Kovács I, Földes T (2007) Geodynamic implications of flattened tabular equigranular textured peridotites from the Bakony-Balaton Highland Volcanic Field (Western Hungary). J Geodyn 43:484-503

Hill KC, Raza A (1999) Arc-continent collision in Papua Guinea: constraints from fission track thermochronology. Tectonics 18:950-966

Hirth G, Kohlstedt DL (1995) Experimental constraints on the dynamics of the partially molten upper mantle; deformation in the dislocation creep regime. J Geophys Res 100(B8):15441-15449

Holtzman BK, Kohlstedt DL (2007) Stress-driven melt segregation and strain partitioning in partially molten rocks: effects of stress and strain. J Petrol 48(12):2379-2406

Holtzman BK, Kohlstedt DL, Zimmerman ME, Heidelbach F, Hiraga T, Hustoft J (2003) Melt segregation and strain partitioning: implications for seismic anisotropy and mantle flow. Science 301:1227-1230

Ionov D (2010) Petrology of mantle wedge lithosphere: new data on supra-subduction zone peridotite xenoliths from the andesitic AvachaVolcano, Kamchatka. J Petrol 51(1):327-361

Ishii T, Robinson PT, Maekawa H, Fiske R (1992) Petrological studies of peridotites from diapiric serpentinite seamounts in The IzuOgasawara-Mariana forearc, LEG125. In: Frey F, Pearce JA, Stokking LB (eds) Proceedings of the ocean drilling program scientific results, vol 125. College Station, TX, pp 445-485

Jackson S (2008) LAMTRACE data reduction software for LAICPMS. Short course series. Mineralogical Association of Canada, Québec

Jaques AL (1978) Marum ophiolite. 1:100 000 scale preliminary map. Australian Bureau Mineral Resources, unpublished

Jaques AL (ed) (1980) Petrologic and experimental studies on the petrogenesis of Papua New Guinea ophiolites. Ph.D. Thesis, University of Tasmania, unpublished

Jaques AL (1981) Petrology and petrogenesis of cumulate peridotites and gabbros from the Marum Ophiolite complex, Nothern Papua New Guinea. J Petrol 22(1):1-40

Jaques AL, Green DH (1980) Anhydrous melting of peridotite at $0-15 \mathrm{~Kb}$ pressure and the genesis of tholeiitic basalts. Contrib Miner Petrol 73:287-310

Jean MM, Shervais JW, Choi S-H, Mukasa SB (2010) Melt extraction and melt refertilization in mantle peridotite of the coast range ophiolite: an LA-ICP-MS study. Contrib Miner Petrol 159:113-136. doi:10.1007/s00410-009-0419-0

Jochum KP, Weis U, Stoll B, Kuzmin DV, Yang Q, Raczek I, Jacob DE, Stracke A, Birbaum K, Frick DA, Günther D, Enzweiler J
(2011) Determination of reference values for NIST SRM 610 617 glasses following ISO guidelines. Geostand Geoanal Res 35(4):397-429. doi:10.1111/j.1751-908X.2011.00120.x

Johnson KTM, Dick HJB (1992) Open system melting and temporal and spatial variation of peridotite and basalt at the Atlantis II fracture zone. J Geophys Res 97(6):9219-9241

Johnson KTM, Dick HJB, Shimizu N (1990) Melting in the oceanic upper mantle: an ion microprobe study of diopsides in abyssal peridotites. J Geophys Res 95:2661-2678

Jung H, Karato SI (2001) Water-induced fabric transitions in olivine. Science 293:1460-1464

Jung H, Katayama I, Jiang Z, Hiraga T, Karato SI (2006) Effect of water and stress on the lattice-preferred orientation of olivine. Tectonophysics 421:1-22

Kaczmarek M-A, Müntener O (2008) Juxtaposition of melt impregnation and high temperature shear zone in the upper mantle; Field and petrological constraints from the Lanzo peridotite (N-Italy). J Petrol 49(12):2187-2220

Kaczmarek M-A, Müntener O (2010) The variability of peridotite composition across a mantle shear zone (Lanzo massif, Italy): interplay of melt focusing and deformation. Contrib Miner Petrol 160:663-679. doi:10.1007/s00410-010-0500-8

Kaczmarek M-A, Reddy S (2013) Mantle deformation during rifting: constraints from quantitative microstructural analysis of olivine from the East African Rift (Marsabit, Kenya). Tectonophysics 608:1122-1137

Kaczmarek M-A, Tommasi A (2011) Anatomy of an extensional shear-zone in the mantle (Lanzo-massif, Italy). Geochem Geophys Geosyst 12:Q0AG06

Karato S, Jung H, Katayama I, Skemer P (2008) Geodynamic significance of seismic anisotropy of the upper mantle: new insights from laboratory studies. Annu Rev Earth Planet Sci 36:59-95

Katayama I, Jung H, Karato SI (2004) New type of olivine fabric from deformation experiments at modest water content and low stress. Geol Soc Am 32(12):1045-1048

Kelemen PB, Shimizu N, Salters VJM (1995) Extraction of midocean-ridge basalt from the upwelling mantle by focused flow of melt in dunite channels. Nature 375:747-753

Kepezhinskas P, Taylor RN, Tanaka H (1993) Geochemistry of plutonic spinels from the North Kamchatka Arc: comparisons with spinels from other tectonic settings. Mineral Mag 57:575-589

Kim D, Jacobi RD (2002) Boninites: characteristics and tectonic constraints, northeastern Appalachians. Phys Chem Earth 27:109-147

Kim D, Jung H (2014) Deformation microstructures of olivine and chlorite in chlorite peridotites from Almklovdalen in the Western Gneiss Region, southwest Norway, and implications for seismic anisotropy. Int Geol Rev 56:1-19. doi:10.1080/002068 14.2014.936054

Kinzler RJ, Grove TL (1993) Corrections and further discussion of the primary magmas of mid-ocean ridge basalts, 1 and 2. J Geophys Res 98:22339-22348

Kneller EA (2007) Trench-parallel flow and seismic anisotropy in the Mariana and Andean subduction systems. Nature 450:1222-1226

Kneller EA, van Keken PE (2008) Effect of three-dimensional slab geometry on deformation in the mantle wedge: implications for shear wave anisotropy. Geochem Geophys Geosyst 9(1):Q01003. doi:10.1029/2007GC001677

Kneller EA, van Keken PE, Karato S, Park J (2005) B-type olivine fabric in the mantle wedge: insights from high resolution nonNewtonian subduction zone models. Earth Planet Sci Lett 237:781-797

Kneller EA, van Keken PE, Katayama I, Karato S (2007) Stress, strain, and B-type olivine fabric in the fore-arc mantle: sensitivity tests using high-resolution steady-state subduction 
zone models. J Geophys Res 112:B04406. doi:10.1029/200 6JB004544

König S, Münker C, Schuth S, Luguet A, Hoffmann JE, Kuduon $\mathrm{J}$ (2010) Boninites as windows into trace element mobility in subduction zones. Geochim Cosmochim Acta 74:684-704

Le Roux V, Dick HJB, Shimizu N (2014) Tracking flux melting and melt percolation in supra-subduction peridotites (Josephine ophiolite, USA). Contrib Miner Petrol 168:1064

Lloyd GE, Farmer AB, Mainprice D (1997) Misorientation analysis and the formation and orientation of subgrain and grain boundaries. Tectonophysics 279:55-78

Lus WY, McDougall I, Davies HL (2004) Age of the metamorphic sole of the Papuan Ultramafic Belt ophiolite, Papua New Guinea. Tectonophysics 392:85-101

Marchesi C, Garrido C, Godard M, Belley F, Ferré E (2009) Migration and accumulation of ultra-depleted subduction-related melts in the Massif du Sud ophiolite (New Caledonia). Chem Geol 266(3-4):180-195

Maury RC, Defant MJ, Joron J-L (1992) Measomatism of sub-arc mantle inferred from trace elements in Philippine xenoliths. Nature 360:661-663

McDonough WF, Sun SS (1995) The composition of the Earth. Chem Geol 120:223-253

Mehl L, Hacker BR, Hirth G, Kelemen PB (2003) Arc-parallel flow within the mantle wedge: evidence from the accreted Talkeetna arc, south central Alaska. J Geophys Res 108(B8):2375

Michibayashi K, Ina T, Kanagawa K (2006) The effect of dynamic recrystallization on olivine fabric and seismic anisotropy: insight from a ductile shear zone, Oman ophiolite. Earth Planet Sci Lett 244:695-708

Michibayashi K, Tasaka M, Ohara Y, Ishii T, Okamoto A, Fryer P (2007) Variable microstructure of peridotite samples from the southern Mariana Trench: evidence of a complex tectonic evolution. Tectonophysics 444:111-118

Michibayashi K, Ohara Y, Stern RJ, Fryer P, Kimura J-I, Tasaka M, Harigane Y, Ishii T (2009) Peridotites from a ductile shear zone within back-arc lithospheric mantle, southern Mariana Trench: results of a Shinkai 6500 dive. Geochem Geophys Geosyst 10(5):Q05X06. doi:10.1029/2008GC002197

Mizukami T, Wallis SR, Yamamoto J (2004) Natural examples of olivine lattice preferred orientation patterns with a flow-normal a-axis maximum. Nature 427:432-436

Monnier C (1996) Mécanismes d'accrétion des domaines océaniques arrière-arc et géodynamique de l'Asie du Sud-Est. Pétrologie et géochimie des ophiolites d'Indonésie (Sulawesi, Haute-Chaîne Centrale, Cyclops, Seram et Meratus). Brest

Morales L, Tommasi A (2011) Composition, textures, thermal and seismic anisotropies of xenoliths from a thin and hot lithospheric mantle (Summit Lake, southern Canadian Cordillera). Tectonophysics 507:1-15

Nicolas A, Poirier J-P (1976) Crystalline plasticity and solid state flow in metamorphic rocks. Wiley, New York

Nicolas A, Bouchez J-L, Boudier F, Mercier J-CC (1971) Textures, structures and fabrics due to solid state flow in some European lherzolites. Tectonophysics 12(1):55-86

Page RW (1976) Geochronology of igneous and metamorphic rocks in the New Guinea Highlands. Bureau Miner Resour J Aust Geol Geophys 162:1-117

Palasse LN, Vissers RLM, Paulssen H, Basu AR, Drury MR (2012) Microstructural and seismic properties of the upper mantle underneath a rifted continental terrane (Baja California): an example of sub-crustal mechanical asthenosphere? Earth Planet Sci Lett 345-348:60-71

Park Y, Jung H (2014) Deformation microstructures of olivine and pyroxene in mantle xenoliths in Shanwang, eastern China, near the convergent plate margin, and implications for seismic anisotropy. Int Geol Rev 56:1-21. doi:10.1080/00206814.2014 .928240

Parkinson IJ, Pearce JA (1998) Peridotites from the Izu-Bonin-Mariana forearc (ODP Leg 125): evidence for mantle melting and melt-mantle interaction in a supra-subduction zone setting. J Petrol 39(9):1577-1618

Parkinson U, Pearce JA, Thirwall MF, Jonhson KTM, Ingram G (1992) Trace element geochemistry of peridotites from IzuBonin-Mariana fore-arc, Leg 125. Proc Ocean Drill Program Sci Results 125:487-506

Participants C (1972) Penrose field conference on ophiolites. Geotimes 17:24-25

Pearce JA, Lippard SJ, Roberts S (1984) Characteristics and tectonic significance of supra-subduction zone ophiolites. In: Kokelaar BP, Howells MF (eds) Marginal basin geology: volcanic and associated sedimentary and tectonic processes in modern and ancient arginal basins, vol 16. Geol Soc Lond, London, pp 77-94

Pearce JA, Barker PF, Edwards SJ, Parkinson IJ, Leat PT (2000) Geochemistry and tectonic significance of peridotites from the South Sandwich arc-basin system, South Atlantic. Contrib Miner Petrol 139:36-53

Prior DJ, Boyle AP, Brenker F, Cheadle MC, Day A, Lopez G, Peruzzo L, Potts GJ, Reddy S, Spiess R, Timms NE, Trimby P, Wheeler J, Zetterström L (1999) The application of electron backscatter diffraction and orientation contrast imaging in the SEM to textural problems in rocks. Am Mineral 84:1741-1759

Prior DJ, Wheeler J, Peruzzo L, Spiess R, Storey C (2002) Some garnet microstructures: an illustration of the potential of orientation maps and misorientation analysis in microstructural studies. J Struct Geol 24:999-1011

Pubellier M, Quebral R, Aurelio M, Rangin C (1996) Docking and post-docking escape tectonics in the southern Philippines. In: Hall R, Blundel D (eds) Geological Society special publications of London, vol 106. Geological Society, London, pp 511-523

Reddy SM, Timms NE, Pantleon W, Trimby P (2007) Quantitative characterization of plastic deformation of zircon and geological implications. Contrib Miner Petrol 153:625-645

Sawaguchi T (2004) Deformation history and exhumation process of the Horoman Peridotite Complex, Hokkaido, Japan. Tectonopysics 379:109-126

Skemer P, Katayama I, Karato SI (2006) Deformation fabrics of the Cima di Gagnone peridotite massif, Central Alps, Switzerland: evidence of deformation at low temperatures in the presence of water. Contrib Miner Petrol 152:43-51

Skemer P, Sundberg M, Hirth G, Cooper R (2011) Torsion experiments on coarse-grained dunite: implications for microstructural evolution when diffusion creep is suppressed. In: Prior DJ, Rutter EH, Tatham DJ (eds) Deformation mechanisms, rheology and tectonics: microstructures, mechanics and anistropy. Special publications, vol 360., Geological SocietyLondon, London, pp 211-223

Sobolev AV, Danyushevsky LV (1994) Petrology and geochemistry of boninites form the north termination of the Tonga trench: constraints on the generation conditions of primary high-Ca boninite magmas. J Petrol 35:1183-1211

Sobolev AV, Migdisov AA, Portnyagin MV (1996) Incompatible element partitioning between clinopyroxene and basalt liquid revealed by the study of melt inclusions in minerals from Troodos lavas, Cyprus. Petrology 4(3):307-317

Song S, Su L (1998) Rheological properties of mantle peridotites at Yushigou in the north Quilian mountains and their implications for plate dynamics. Acta Geol Sin 72(2):131-141

Song S, Su L, Niu Y, Lai Y, Zhang L (2009) CH4 inclusions in orogenic harzburgite: evidence for reduced slab fluids and implication for redox melting in mantle wedge. Geochim Cosmochim Acta $73: 1737-1754$ 
Soustelle V, Tommasi A, Demouchy S, Ionov DA (2010) Deformation and fluid-rock interaction in the supra-subduction mantle: microstructures and water contents in the peridotite xenoliths from the Avacha volcano, Kamchatka. J Petrol 51(1-2):363-394

Soustelle V, Tommasi A, Demouchy S, Franz L (2013) Melt-rock interactions, deformation, hydration and seismic properties in the sub-arc lithospheric mantle inferred from xenoliths from seamounts near Lihir, Papua New Guinea. Tectonophysics 608:330-345

Stern RJ, Bloomer SH (1992) subduction zone infancy; examples from the Eocene Izu-Bonin-Mariana and Jurassic California arcs. Geol Soc Am Bull 104:1621-1636

Suhr G, Hellebrand E, Snow J, Seck HA, Hofmann AW (2003) Significance of large, refractory dunites bodies in the upper mantle of the Bay of Islands Ophiolite. Geochem Geophys Geosyst 4:1-34

Sundberg M, Hirth G, Kelemen PB (2010) Trapped melt in the Josephine peridotite: implications for permeability and melt extraction in the upper mantle. J Petrol 51(1 \& 2):185-200

Tamura A, Arai S (2006) Harzburgite-dunite-orthopyroxenite suite as a record of supra subduction zone setting for the Oman ophiolite mantle. Lithos 90:43-56

Tasaka M, Michibayashi K, Mainprice D (2008) B-type olivine fabrics developed in fore-arc side of the mantle wedge along subducting slab. Earth Planet Sci Lett 272:747-757

Tommasi A, Mainprice D, Canova G, Chastel Y (2000) Viscoplastic self-consistent and equilibrium-based modeling of olivine lattice preferred orientations: implications for the upper mantle seismic anisotropy. J Geophys Res 105(B4):7893-7908

Tommasi A, Godard M, Coromina G, Dautria JM, Barsczus H (2004) Seismic anisotropy and compositionally induced velocity anomalies in the lithosphere above mantle plumes: a petrological and microstructural study of mantle xenoliths from French Polynesia. Earth Planet Sci Lett 227:539-556

Umino S (1986) Magma mixing in boninite sequence of Chichijima, Bonin Island. J Volcanol Geoth Res 29:125-157

van der Laan SR, Arculus RJ, Pearce JA, Murton BJ (1992) Petrography, mineral chemistry, and phase relations of the basement boninite series of Site 786, Izu-Bonin forearc. In: Fryer P, Pearce JA, Stokking LB (eds) Proceedings of the ocean drilling program, scientific results, vol 125. Ocean Drilling Program, College Station, pp 171-202

Van Roermund HLM, Boland J (1981) The dislocation substructures of naturally deformed omphacites. Tectonophysics 78:403-418

Walker DA, McDougall I (1982) ${ }^{40} \mathrm{Ar} /{ }^{39} \mathrm{Ar}$ and $\mathrm{K}-\mathrm{Ar}$ dating of altered glassy volcanic rocks: the Dabi volcanics, PNG. Geochim Cosmochim Acta 46:2181-2190

Wang Q, Xia Q-K, O'Reilly S, Griffin WL, Beyer EE, Brueckner HK (2013) Pressure- and stress-induced fabric transition in olivine from peridotites in the Western Gneiss Region (Norway): implications for mantle seismic anisotropy. J Metamorph Geol 31:93-111. doi:10.1111/jmg.12011

Wasylenki LE, Baker MB, Kent AJR, Stolper EM (2003) Nearsolidus melting of the shallow upper mantle: partial melting experiments on depleted peridotite. J Petrol 44:1163-1191

Webber CE, Little T, Newman J, Tikoff B (2008) Fabric superposition in upper mantle peridotite, Red Hills, New Zealand. J Struct Geol 30:1412-1428

Whattam SA (2009) Arc-continent collisional orogenesis in the SW Pacific and the nature, source and correlation of emplaced ophiolitic nappe components. Lithos 113:88-114

Whattam SA, Malpas J, Ali JR, Smith IEM (2008) New SW Pacific tectonic model: cyclical intraoceanic magmatic arc construction and near-coeval emplacement along the Australia-Pacific margin in the Cenozoic. Geochem Geophys Geosyst 9(3):Q03021. doi:10.1029/2007GC001710

Witt-Eickschen G, Seck HA (1991) Solubility of Ca and Al in orthopyroxene from spinel peridotite; an improved version of an empirical geothermometer. Contrib Miner Petrol 106(4):431-439

Zhou M-F, Robinson PT, Malpas J, Edwards SJ, Liang Q (2005) REE and PGE geochemical constraints on the formation of dunites in the Luobusa Ophiolite, Southern Tibet. Contrib Miner Petrol 46:615-639 